\title{
Mineralogy and biogeochemistry of potassium in the Skogaby experimental forest, southwest Sweden: pools, fluxes and $K / R b$ ratios in soil and biomass
}

\author{
Magnus Simonsson $(\mathbb{D} \cdot$ Mélanie Court $\cdot$ Johan Bergholm $\cdot$ Damien Lemarchand $\cdot$ Stephen Hillier
}

Received: 3 December 2015/Accepted: 15 October 2016/Published online: 26 October 2016

(C) The Author(s) 2016. This article is published with open access at Springerlink.com

\begin{abstract}
Clay minerals and $\mathrm{K}$ feldspars were evaluated as sources of $\mathrm{K}$ in a Norway spruce stand (Picea abies (L.) Karst.) from the Skogaby experimental forest in southwest Sweden. The soil, developed in a Quaternary glacial till, has only 3-5\% clay, and more than $95 \%$ of its $\mathrm{K}$ resides in feldspars. Ratios of $\mathrm{K} / \mathrm{Rb}$ were assessed in interlayers of 2:1 clay minerals (extracted with hot $\left.\left(100^{\circ} \mathrm{C}\right) 2 \mathrm{M} \mathrm{HCl}\right)$, biomass and the forest floor. These compartments had similarly low $\mathrm{K} / \mathrm{Rb}$ ratios, whereas $\mathrm{K}$ feldspars were significantly poorer in $\mathrm{Rb}$. A fractionation model indicated preferential retention of $\mathrm{Rb}$ in the biomass and forest floor, due to stronger adsorption of $\mathrm{Rb}$ than $\mathrm{K}$ in the humus,
\end{abstract}

Responsible Editor: Marc G. Kramer

M. Simonsson $(\bowtie) \cdot$ S. Hillier

Department of Soil and Environment, Swedish University

of Agricultural Sciences (SLU), P.O. Box 7014,

75007 Uppsala, Sweden

e-mail: magnus.simonsson@slu.se

S. Hillier

e-mail: stephen.hillier@hutton.ac.uk

M. Court

INRA, Centre de Nancy, Biogéochimie des Écosystèmes Forestiers, Route d'Amance, 54280 Champenoux, France e-mail: melanie.court@inra.fr

Present Address:

J. Bergholm

Kantarellvägen 6, 75645 Uppsala, Sweden

e-mail: jabergholm@gmail.com as well as preferential uptake of $\mathrm{K}$ from the exchange complex in the mineral soil. Preferential uptake of $\mathrm{K}$ may result from weaker adsorption of $\mathrm{K}$ by the cation exchanger, or preference for dissolved $\mathrm{K}$ over $\mathrm{Rb}$ by the roots. A quantitative mineralogical analysis revealed that loss from micas may account for half of the Holocene loss of $\mathrm{K}$ from the soil, which was approximately $22 \mathrm{Mg} \mathrm{ha}^{-1}$. Exceptionally low $\mathrm{K} / \mathrm{Rb}$ ratios in $\mathrm{HCl}$ extracts of the upper $60 \mathrm{~cm}$ of the profile indicated extensive loss of $\mathrm{K}$ from mica in the parent material and re-fixation of $\mathrm{K}$ and $\mathrm{Rb}$ at lower ratios. The results indicate that fixation in and release from clay minerals may be prominent in the cycling of $\mathrm{K}$, even in a soil that is poor in clay minerals.

\author{
J. Bergholm \\ Department of Ecology, Swedish University of \\ Agricultural Sciences (SLU), P.O. Box 7044, \\ 75007 Uppsala, Sweden \\ D. Lemarchand \\ Laboratoire d'Hydrologie et de Géochimie de Strasbourg, \\ EOST, Université de Strasbourg and CNRS, 1 rue Blessig, \\ 67084 Strasbourg Cedex, France \\ e-mail: damien.lemarchand@unistra.fr \\ S. Hillier \\ The James Hutton Institute, Craigiebuckler, \\ Aberdeen AB15 8QH, Scotland, UK
}


Keywords Forest ecosystem - Potassium cycle $\cdot \mathrm{K} /$ $\mathrm{Rb}$ ratio $\cdot$ Mica $\cdot$ Clay minerals $\cdot$ Feldspar

\begin{tabular}{|c|c|}
\hline \multicolumn{2}{|c|}{ Abbreviations } \\
\hline ANOVA & Analysis of variance \\
\hline $\mathrm{BP}$ & Before present \\
\hline $\mathrm{C}$ & $\begin{array}{l}\text { Control (refers to plots in the field } \\
\text { experiment) }\end{array}$ \\
\hline EDTA & Ethylene diamine tetra-acetic acid \\
\hline EPA & $\begin{array}{l}\text { Environmental protection agency of the } \\
\text { United States }\end{array}$ \\
\hline FAO & $\begin{array}{l}\text { Food and Agriculture Organization of the } \\
\text { United Nations }\end{array}$ \\
\hline $\begin{array}{l}\text { IAP- } \\
\text { AES }\end{array}$ & $\begin{array}{l}\text { Inductively coupled plasma atomic } \\
\text { emission spectroscopy }\end{array}$ \\
\hline $\begin{array}{l}\text { ICP- } \\
\text { SFMS }\end{array}$ & $\begin{array}{l}\text { Inductively coupled plasma sector field } \\
\text { mass spectroscopy }\end{array}$ \\
\hline NaTPB & Sodium tetraphenyl borate \\
\hline NS & $\begin{array}{l}\text { Ammonium sulphate treatment (refers to } \\
\text { plots in the field experiment) }\end{array}$ \\
\hline$\AA$ & Ångström $\left(1 \AA=10^{-10} \mathrm{~m}\right)$ \\
\hline
\end{tabular}

\section{Introduction}

In the undisturbed forest ecosystem, nutrient supply is mainly achieved by continual recycling of elements. Forest ecosystems that are subject to harvesting of timber or biofuel, on the other hand, often show declining nutrition status, due to poor geochemistry and mineralogy that fail to compensate for the export of nutrients (Olsson et al. 1993). Such soils also show a tendency to develop enhanced soil acidity when exposed to pollution. National calculations indicate that the supply of the essential base cations $\left(\mathrm{Ca}^{2+}\right.$, $\mathrm{Mg}^{2+}, \mathrm{K}^{+}$) is not sufficient to sustain current levels of forest harvest in large areas of Sweden (Akselsson et al. 2007).

Potassium (K) is an essential element for all living organisms. In plants, it is involved in photosynthesis, formation and migration of sugars and proteins and in the regulation of osmotic pressure and enzyme activity (Marschner 1995). Adequate supply of K improves the mechanical strength of plant tissues and enhances resistance to plant pathogens, as well as the capacity of the plant to endure stress caused by drought or low temperature. In forest ecosystems, $\mathrm{K}$ is a vigorously cycled element that is potentially growth limiting and whose concentrations in surface water, unlike other base cations, displays seasonal dynamics resembling those of $\mathrm{N}$ (Tripler et al. 2006). The mineralogical reserve of $\mathrm{K}$ in soils is essentially restricted to $\mathrm{K}$ present in feldspars and interlayer sites of micas (biotite, muscovite) and 2:1 clay minerals such as illite and mixed-layer minerals (illite/vermiculite, illite/ smectite). Pot experiments and acid extractions conducted a long time ago showed that $\mathrm{K}$ in mica and clay minerals is more prone to release by weathering than $\mathrm{K}$ in feldspar (Prianischnikow 1906; Mortland et al. 1957; Ståhlberg 1958). Mobilisation of $\mathrm{K}^{+}$from interlayer sites in clay minerals occurs when the concentration of $\mathrm{K}$ in the ambient solution is lower than a critical threshold value (Fanning et al. 1989). The mechanism includes diffusion between 2:1 layers of the clay (Mortland and Ellis 1959; Reed and Scott 1962) and is a reversible reaction. Thus, fixation of $\mathrm{K}$ may result from $\mathrm{K}$ additions to the soil. However, the presence of organic matter and hydroxide interlayers may decrease the capacity of clay minerals to fix both $\mathrm{K}^{+}$and geochemically similar cations like $\mathrm{Rb}^{+}$(Ross 1971; Chaudhuri et al. 2007).

At the decennial time-scale, subtle changes in clay mineralogy caused by depletion and replenishment of $\mathrm{K}$ through management practices have been observed and characterised in several studies (Velde and Peck 2002; Barré et al. 2007a, b, 2008; Simonsson et al. 2009). Studies with high resolution in time and space have shown that root-soil interactions may alter the $\mathrm{K}$ content of clay minerals in forest soils in the lapse of only a few months to an extent that may be measured with conventional mineralogical and geochemical methods (Turpault et al. 2007, 2008; Calvaruso et al. 2009). We have previously shown that $\mathrm{K}$ extracted with $2 \mathrm{M} \mathrm{HCl}$ at $100{ }^{\circ} \mathrm{C}$, ' $\mathrm{K}_{\mathrm{HCl}}$ ' (Egnér et al. 1960), traditionally used to analyse 'reserve $\mathrm{K}$ ' in agricultural soils, represents a significant proportion (of the order of $10-20 \%$ ) of the K held in clay minerals (AndristRangel et al. 2006). Although this may be an order of magnitude more than the pool of exchangeable $\mathrm{K}$ in the soil, $\mathrm{K}_{\mathrm{HCl}}$ was shown to be a dynamic pool that responded to uptake by crops and application of fertilizer in long-term field experiments (Simonsson et al. 2007). Applying quantitative and differential $\mathrm{X}$-ray diffraction methods on soil samples before and after extraction, we demonstrated that the $\mathrm{HCl}$ extraction targeted a fraction of $\mathrm{K}$ held in Fe-rich, dioctahedral illite/vermiculite mixed-layer clay with a 
high propensity for both release and fixation of $\mathrm{K}^{+}$. In addition, $\mathrm{K}$ from trioctahedral mica (biotite/phlogopite) was extracted, if present. Because the extraction mechanism is partial 2:1 layer destruction rather than just simple removal of the interlayer $\mathrm{K}$, it can be assumed that other interlayer cations may be extracted from the same mineral phases that are the source of $\mathrm{K}_{\mathrm{HCl}}$. The contribution to $\mathrm{K}_{\mathrm{HCl}}$ from $\mathrm{K}$ feldspars appeared to be of minor importance; the largest contribution was found in a loamy sand with a small content of clay minerals, where it was estimated that $10-30 \%$ of the $\mathrm{K}_{\mathrm{HCl}}$ was derived from feldspars (Andrist-Rangel et al. 2013). However, the possible importance, in the field situation, of $\mathrm{K}$ feldspars in soils that are poor in K-bearing 2:1 clay minerals remains unclear.

Rubidium is mainly held by the same feldspars and phyllosilicates that contain K (Salminen 2005). The $\mathrm{K} / \mathrm{Rb}$ ratio decreases during the evolution of magmas and is used as an index in studies of magmatic rocks (Shaw 1968). Depending on rock type, the ratio varies between 35 to 650 (Ahrens 1965; Wedepohl 1969; Bowen 1979). Because both adsorption and fixation of $\mathrm{Rb}^{+}$in clay minerals are stronger due to a lower hydration energy compared to $\mathrm{K}^{+}, \mathrm{Rb}$ is retained more strongly than $\mathrm{K}$ in the solid phase upon weathering of rocks and minerals (Sawhney 1964; Heier and Billings 1970). As a result, the $\mathrm{K} / \mathrm{Rb}$ ratio generally decreases during the process of soil formation (Kabata-Pendias 2001), and the soil solution may have a higher K/Rb ratio than the clay minerals at equilibrium (Chaudhuri et al. 2007). While $\mathrm{Rb}$ is not considered an essential element in biological processes, it has been used as a tracer for K (Kuhlmann et al. 1985; Kuhlmann 1990; Witter and Johansson 2001), due to their purportedly similar biogeochemical behaviour. However, there is considerable ambiguity regarding the similarities and differences between the cycles of $\mathrm{K}$ and $\mathrm{Rb}$ in the soilplant-hydrosphere system. Whereas several studies support the idea of a similar behaviour of the ions (Collander 1941; Burr and Tanimoto 1955; Vakhmistrov and Zakharin 1968; Wallace 1968; Bouat 1969), others point out a preference for either of the elements by roots (Menzel and Heald 1955; Maas and Legett 1968; White et al. 2012). The complexity of the problem was demonstrated in a study on maize roots by Läuchli and Epstein (1970), where shortage of calcium $(\mathrm{Ca})$ induced preferential loss of $\mathrm{K}$, whereas in the presence of $\mathrm{Ca}, \mathrm{K}$ and $\mathrm{Rb}$ showed a similar behaviour. Wyttenbach et al. (1995a) concluded that $\mathrm{Rb}^{+}$and $\mathrm{Cs}^{+}$were more mobile in living plant tissues than the smaller and more strongly hydrated $\mathrm{K}^{+}$or $\mathrm{Na}^{+}$ions, and therefore more rapidly lost from living spruce needles. From decomposing needle litter of Norway spruce, however, K was released preferentially over Rb in experiments by Peltola et al. (2008). During uptake by roots, it was argued that emerging $\mathrm{K} / \mathrm{Rb}$ ratios was mainly a result of sorption properties of the soil, where the presence of clay minerals with a propensity for fixing alkali cations would hamper the uptake of $\mathrm{Rb}^{+}$and $\mathrm{Cs}^{+}$, thereby increasing the $\mathrm{K} / \mathrm{Rb}$ ratio in the biomass (Wyttenbach et al. 1995a, b).

The objective of the present study was to quantify the importance of different sources of $\mathrm{K}$ in the Skogaby experimental forest in southwest Sweden, where base cation weathering rates were recently estimated from nutrient budgets by Simonsson et al. (2015). We particularly intended to test the ratio of potassium $(\mathrm{K})$ over rubidium $(\mathrm{Rb})$ extracted from clay minerals as an index of bio-cycling of $\mathrm{K}$ in the root zone of forest soils. The following hypotheses were raised:

1. In the long term, weathering of $\mathrm{K}$ feldspars is an important source of biogeochemically active $\mathrm{K}$ in a soil-plant system developed on a parent material poor in K-bearing 2:1 clay/phyllosilicate minerals.

2. $\mathrm{K} / \mathrm{Rb}$ ratios in hot $\left(100{ }^{\circ} \mathrm{C}\right) 2 \mathrm{M} \mathrm{HCl}$ extracts of the soil show a vertical gradient in the soil profile that can be used to measure the influence of biocycling in the root zone, particularly regarding the amount of $\mathrm{K}$ held by clay minerals that has been cycled through the biomass over extended time periods.

3. Treatments that enhance tree growth in forest management experiments (e.g., nitrogen fertilization, irrigation) on the decennial time scale result in enhanced bio-cycling of $\mathrm{K}$, which can be measured according to Hypothesis 2.

\section{Materials and methods}

Site description

The Skogaby site $\left(56^{\circ} 33^{\prime} 15^{\prime \prime} \mathrm{N}, 13^{\circ} 12^{\prime} 54^{\prime \prime} \mathrm{E}\right)$ is situated $17 \mathrm{~km}$ from the coast of southwest Sweden at $95-125 \mathrm{~m}$ above sea level and 35-65 $\mathrm{m}$ above the 
upper post-glacial marine limit (Daniel 2006). The climate is maritime with a mean annual temperature and precipitation of $7.6^{\circ} \mathrm{C}$ and $1187 \mathrm{~mm}$, respectively. The vegetation period extends over 200 days, from the beginning of April to the beginning of November. The dominating bedrock in the area is gneiss with granitic, granodioritic or tonalitic mineralogy (Daniel 2006). At the Skogaby site, it is overlaid by $>2 \mathrm{~m}$ of glacial till (Bergholm et al. 2003) of granitic composition according to the data presented in this paper. These so-called Halland Coastal Moraines may have been formed as early as 18,000 years before present (BP) and were deglaciated around 15,000 year BP (Lundqvist and Wohlfarth 2001). Periods of climate warming, with invasion of birch (Betula sp.), were intercalated by cold events, with extensive formation of patterned ground on the nearby coastal plain, until a drastic warming occurred around 11,200 year BP at the transition to the postglacial warm period (Daniel 2006). The soil is a Haplic Podzol (FAO 1990) consisting of a $5-\mathrm{cm}$ thick $\mathrm{O}$ horizon on a mineral soil with a fine-earth texture of loamy sand (4\% clay, 32\% silt and 64\% sand) (Bergholm et al. 2003). Below the $\mathrm{O}$ horizon is a weakly developed $5 \mathrm{~cm}$ thick $\mathrm{E}$ horizon, which is dark-coloured due to its content of organic matter, and a B horizon extending to $60 \mathrm{~cm}$ depth (Bergholm et al. 2001). Soil chemical data are shown in Table 1. The clay mineralogy, as described by Courchesne and Gobran (1997), is mainly vermiculitic and therefore poor in phyllosilicates with remaining interlayer $\mathrm{K}$.

In 1913, the former Calluna moorland was planted with Scots pine (Pinus sylvestris L.). This stand was replaced by Norway spruce (Picea abies (L.) Karst.) in 1966. In 1988, a randomised block $(n=4)$ experiment was started to test the effects of deposition and nutritional conditions on the vitality and growth of the trees. The treatments included ammonium-sulphate applications, nitrogen-free fertilisation, irrigation, irrigation fertilisation and drought (Nilsson and Wiklund 1994; Bergholm et al. 1995). When the experimental treatments started in 1988, the trees were 25 year old, including three years in the nursery. Treatments and control (no treatment) were applied in plots of $45 \mathrm{~m}$ by $45 \mathrm{~m}\left(2025 \mathrm{~m}^{2}\right)$. In 1993, the stand was thinned by removing $25 \%$ of the basal area of all plots, which corresponded to a reduction of the biomass by $14 \%$ on average (all above-ground biomass of felled trees were removed from the plots). The study presented in this paper was performed within two control plots (abbreviated ' $\mathrm{C}$ ') and two plots treated with ammonium sulphate ('NS'). Two of the plots, C24 and NS19, belonged to Block I, planted with seedlings of the provenance Istebna; the remaining two, C3 and NS7, belonged to Block IV planted with Augustow (Bergholm et al. 1995) and situated in a part of the experiment characterised by a lower productivity class. The NS treatment was aimed at studying the effects of acidification and eutrophication due to large depositions of N and S. Granulated ammonium sulphate was applied three times per year (May, June and July) at a rate of 100 and $114 \mathrm{~kg} \mathrm{ha}^{-1}$ year $^{-1}$ of $\mathrm{N}$ and $\mathrm{S}$, respectively, corresponding to six times the annual deposition rate at the time the experiment was started (Nilsson and Wiklund 1995).

Table 1 Soil chemistry at the Skogaby site prior to the start of the experiment in 1987

\begin{tabular}{|c|c|c|c|c|c|c|c|c|c|c|c|c|c|}
\hline Soil layer $(\mathrm{cm})$ & $\begin{array}{l}\text { Sand } \\
\text { (\% of } \\
<2 \text { m }\end{array}$ & $\begin{array}{l}\text { Silt } \\
\text { ted } \mathrm{f}\end{array}$ & $\begin{array}{l}\text { Clay } \\
\text { arth }\end{array}$ & $\mathrm{C} / \mathrm{N}$ & $\begin{array}{l}\mathrm{pH} \\
\left(\mathrm{H}_{2} \mathrm{O}\right)\end{array}$ & $\mathrm{CEC}_{\text {eff }}\left(\mathrm{mmol}_{\mathrm{c}} \cdot \mathrm{kg}^{-1}\right)$ & $\begin{array}{l}\mathrm{BS} \\
(\% \mathrm{o}\end{array}$ & $\begin{array}{l}\mathrm{Na} \\
\mathrm{CEC}\end{array}$ & $\begin{array}{l}K \\
\text { eff) }\end{array}$ & $\mathrm{Mg}$ & $\mathrm{Ca}$ & $\mathrm{Al}$ & $\mathrm{H}$ \\
\hline Humus & & & & 25.7 & 3.91 & 240.4 & 29.8 & 1.5 & 4.4 & 7.5 & 16.6 & 16.0 & 54.0 \\
\hline $0-10$ & 64 & 31 & 5 & 23.1 & 4.07 & 55.5 & 8.4 & 1.9 & 1.2 & 1.9 & 3.3 & 65.6 & 25.9 \\
\hline $10-20$ & 64 & 30 & 5 & 21.7 & 4.44 & 34.8 & 6.9 & 2.3 & 0.9 & 1.1 & 2.5 & 77.3 & 15.8 \\
\hline $20-30$ & 64 & 31 & 5 & 20.8 & 4.46 & 27.4 & 8.3 & 2.4 & 0.9 & 1.4 & 3.6 & 75.5 & 16.1 \\
\hline $30-40$ & 64 & 32 & 4 & 20.4 & 4.51 & 18.9 & 11.0 & 3.5 & 1.2 & 1.8 & 4.6 & 73.0 & 16.4 \\
\hline $40-50$ & 66 & 31 & 3 & 20.2 & 4.54 & 13.9 & 12.4 & 4.4 & 1.5 & 2.2 & 4.5 & 69.1 & 18.7 \\
\hline
\end{tabular}

Chemistry data from Bergholm et al. (2003); texture (sand, silt and clay) from the COUP model (unpublished data) 
Sampling of soil, humus and biomass

Soil samples used in this study were taken in 1999 from two control plots (C3 and C24) and two NS plots (NS7 and NS19). In each plot, a pit was dug to $100 \mathrm{~cm}$ and soil collected from eleven depths of the mineral soil: $0-5,5-10,10-20, \ldots, 80-90$ and $90-100 \mathrm{~cm}$. Litter and humus-layer materials were sampled plotwise in December 2001. Within each plot 40 evenly distributed points were sampled with a steel cylinder (5.6 $\mathrm{cm}$ inner diameter) and bulked to yield one litter and one humus sample representing the plot. From the same plots, in total ten representative trees (two or three trees in each of the plots investigated in this study) were felled in April 2001. For our study, needle samples from 4 to 9 different levels in the canopy of the ten trees were pooled according to the dry-weight of each canopy level, to yield one representative sample per tree. Stem wood and bark samples were pooled similarly from discs obtained from five positions along the trunk. Samples from 1999 to 2001 were considered contemporaneous in the present study.

Mineralogy of fine earth and clay fraction

Quantitative bulk mineralogy of the fine earth $(<2 \mathrm{~mm})$ was assessed at all eleven depths of the mineral soil from the four plots sampled in 1999 using powder X-ray diffraction. Random powders were prepared by wet McCrone milling of 3.0-g samples for 12 min and spray drying of the slurries directly after the milling (Hillier 1999, 2003). All random powders were run on a Panalytical Xpert pro diffractometer, using Ni-filtered $\mathrm{Cu}-\mathrm{K} \alpha$ radiation scanning from 3 to $70^{\circ} 2 \theta$ in $0.0167^{\circ} 2 \theta$ steps and counting for $100 \mathrm{~s}$ per step with a position-sensitive X-celerator detector. Quantitative mineralogical analysis was carried out by a full-pattern fitting method similar to that described for participant 18 (p18) in Omotoso et al. (2006), but without an internal standard. With this method, reference patterns of pure minerals and non-crystalline phases were fitted to the observed diffraction patterns using least squares minimisation of an objective function. The calculations were made using an Excel spreadsheet and the Solver add-in. Small offsets in $2 \theta$ between patterns were accommodated by a cubic spline interpolation, as suggested by Schulze (1986). Table 2 lists the individual mineral phases used for the full-pattern fitting.
In addition, a qualitative analysis was performed on parallel-orientated clay fractions $(<2 \mu \mathrm{m})$ of soil from 0 to $100 \mathrm{~cm}$ depth in plot $\mathrm{C} 24$, prepared using a filter peel method (Moore and Reynolds 1997). All orientated mounts were analysed air-dried, ethylene glycolated and after heating to $300{ }^{\circ} \mathrm{C}$ for $1 \mathrm{~h}$. Diffraction patterns were measured on a Bruker D8 instrument, scanning from 2.5 to $45^{\circ} 2 \theta$ and counting for $16.5 \mathrm{~s}$ per $0.02048^{\circ} 2 \theta$ step with a position-sensitive Lynxeye XE detector. To determine the dioctahedral versus trioctahedral nature of the minerals in the clay fraction, aliquots of the clay fractions from 0-5, 30-40 and $80-90 \mathrm{~cm}$ depths were treated with $6 \mathrm{M} \mathrm{HCl}$ for $30 \mathrm{~min}$ at $90{ }^{\circ} \mathrm{C}$, to destroy the trioctahedral phases (Hayashi and Oinuma 1964). Following treatment, patterns of air-dried, glycolated and heated mounts were obtained as above.

\section{Extractions with $\mathrm{HCl}$ and $\mathrm{NaTPB}$}

$\mathrm{HCl}$ extraction was performed on soil and humus samples according to the procedure of Egnér et al. (1960): Samples (2 g) were placed in glass flasks and $50 \mathrm{ml}$ of $2 \mathrm{M} \mathrm{HCl}$ was added; the latter was prepared from $65 \%$ suprapure $\mathrm{HCl}$ and ultrapure water. The flasks were put in boiling water for $2 \mathrm{~h}$ and swirled every $30 \mathrm{~min}$. After $2 \mathrm{~h}$, they were immersed in cool $\left(10{ }^{\circ} \mathrm{C}\right)$ water to stop the reaction. Then, the extracts were filtered through paper filters (Munktell $00 \mathrm{H}$, Grycksbo, Sweden) and stocked in a refrigerator until shipped to an external laboratory for analysis of $\mathrm{K}$ and $\mathrm{Rb}$ concentrations by inductively coupled plasma sector field mass spectrometry (ICP-SFMS) using a modified version of EPA 200.8.

Extraction with sodium tetraphenylborate (NaTPB) was performed on five horizons from the mineral soil $(0-5,10-20,30-40,50-60,90-100 \mathrm{~cm})$ according to the procedure of Cox et al. (1999). The TPB anion forms insoluble precipitates with $\mathrm{K}^{+}$and $\mathrm{Rb}^{+}$, and thereby extracts both ions selectively from clay minerals (Paul and Gibson 1959; Reed and Scott 1962). It has a similar action on $\mathrm{Rb}$ (Taskaev 1987). NaTPB removed $70-80 \%$ of $\mathrm{K}$ from dioctahedral mica/smectite as reported by Ross and Kodama (1970). In work on Canadian Podzols, as little as 10-30\% was extracted from the most weathered Ae horizons of the most weathered profiles, 40-65\% from less weathered soils (Ross 1971). Samples $(0.5 \mathrm{~g})$ were placed in $50-\mathrm{ml}$ centrifugation tubes 
Table 2 Mineral phases used for the full-pattern fitting to assess the quantitative mineralogy of the bulk fine earth $(<2$ mm)

\begin{tabular}{|c|c|c|c|}
\hline Category & $\begin{array}{l}\text { Mineral } \\
\text { group }\end{array}$ & $\begin{array}{l}\text { Idealised formulas used to calculate formula } \\
\text { weights }\end{array}$ & $\begin{array}{l}\text { Formula weight }\left(\mathrm{g} \mathrm{mol}^{-1}\right) \text { used to } \\
\text { estimate } \mathrm{K} \text { loss from phyllosilicates }\end{array}$ \\
\hline \multirow[t]{4}{*}{ Primary silicates } & Quartz & & \\
\hline & Plagioclases & & \\
\hline & $\mathrm{K}$ feldspars & $\mathrm{KAlSi}_{3} \mathrm{O}_{8}$ & \\
\hline & Amphiboles & & \\
\hline Oxides & Goethite & & \\
\hline $\begin{array}{l}\text { Dioctahedral } \\
\text { K-bearing 2:1 } \\
\text { mineral }\end{array}$ & Muscovite & $\mathrm{KAl}_{2} \mathrm{Si}_{3} \mathrm{AlO}_{10}(\mathrm{OH})_{2}$ & 398 \\
\hline \multirow{3}{*}{$\begin{array}{l}\text { Trioctahedral } \\
\text { K-bearing 2:1 } \\
\text { minerals }\end{array}$} & Biotite & $\mathrm{KFe}_{1.5} \mathrm{Mg}_{1.5} \mathrm{Si}_{3} \mathrm{AlO}_{10}(\mathrm{OH})_{2}$ & 465 \\
\hline & Phlogopite & $\mathrm{KMg}_{3} \mathrm{Si}_{3} \mathrm{AlO}_{10}(\mathrm{OH})_{2}$ & 417 \\
\hline & Hydrobiotite & $\left(\mathrm{Ca} \cdot 6 \mathrm{H}_{2} \mathrm{O}\right)_{0.25} \mathrm{~K}_{0.5} \mathrm{Fe}_{1.5} \mathrm{Mg}_{1.5} \mathrm{Si}_{3.5} \mathrm{Al}_{0.5} \mathrm{O}_{10}(\mathrm{OH})_{2}^{\mathrm{a}}$ & 443 \\
\hline \multirow{2}{*}{$\begin{array}{l}\text { Expandable } 2: 1 \\
\text { minerals }\end{array}$} & Vermiculite & $\left(\mathrm{Ca} \cdot 6 \mathrm{H}_{2} \mathrm{O}\right)_{0.35} \mathrm{Mg}_{3} \mathrm{Si}_{3.3} \mathrm{Al}_{0.7} \mathrm{O}_{10}(\mathrm{OH})_{2}^{\mathrm{a}}$ & 430 \\
\hline & Smectite & $\left(\mathrm{Ca} \cdot 12 \mathrm{H}_{2} \mathrm{O}\right)_{0.25} \mathrm{Al}_{1.5} \mathrm{Mg}_{0.5} \mathrm{Si}_{4} \mathrm{O}_{10}(\mathrm{OH})_{2}^{\mathrm{a}}$ & 423 \\
\hline $1: 1$ mineral & Kaolinite & & \\
\hline Amorphous phases & $\begin{array}{l}\text { Amorphous } \\
\text { Fe oxides }\end{array}$ & & \\
\hline
\end{tabular}

a Calcium-saturated forms are improbable in the present soil, but were used as standards in the calibration in full-pattern fitting for quantitative mineralogy. Hydration numbers of exchangeable $\mathrm{Ca}^{2+}$ are estimates with some uncertainty

with $1 \mathrm{ml}$ of $5.1 \mathrm{M} \mathrm{NaCl}, 1 \mathrm{ml}$ of $0.03 \mathrm{M}$ EDTA and $1 \mathrm{ml}$ of $0.6 \mathrm{M}$ NaTPB. At the same time, 25-225 $\mu \mathrm{l}$ of $1 \mathrm{M} \mathrm{NaOH}$ was added to each sample to perform the extraction at a standardised $\mathrm{pH}$ of approximately 6.0. The required dose of base had been established in a pilot experiment using soil from different depths in the profile. After an incubation period of 15 days, $25 \mathrm{ml}$ of quenching solution $\left(0.5 \mathrm{M} \mathrm{NH} \mathrm{NH}_{4} \mathrm{Cl}\right.$ and $0.11 \mathrm{M} \mathrm{CuCl}_{2}$ ) was added to stop the extraction of $\mathrm{K}$ and $\mathrm{Rb}$. Solutions were transferred to $50 \mathrm{ml}$ glass tubes and placed in a digestion block heated to $150{ }^{\circ} \mathrm{C}$ until the precipitates dissolved completely (30-45 min). Ultrapure water was added to a total volume of $50 \mathrm{ml}$ and the extracts were left for the soil to settle during $30 \mathrm{~min}$. An aliquot of approximately $20 \mathrm{ml}$ of supernatant was then transferred to $50 \mathrm{ml}$ centrifuge tubes and three drops of $6 \mathrm{M} \mathrm{HCl}$ were added, to prevent precipitation of $\mathrm{Cu}^{2+}$ with degradation products of the NaTPB. After centrifugation $(5 \mathrm{~min}$ at $2600 \times \mathrm{g}$ ), the samples were stocked in a refrigerator until sent for analysis of $\mathrm{K}$ and $\mathrm{Rb}$ by ICP-SFMS.
Exchangeable cations and $\mathrm{pH}$

Exchangeable cations in mineral soil horizons $(0-100 \mathrm{~cm})$ were extracted from air-dried samples, using $1 \mathrm{M} \mathrm{NH}_{4} \mathrm{Cl}$. Samples of $1 \mathrm{~g}$ soil were introduced into $50-\mathrm{ml}$ polypropylene centrifuge tubes and $10 \mathrm{ml}$ extractant was added. After reciprocating shaking (30 $\mathrm{min}, 200 \mathrm{~min}^{-1}$ ), the samples were centrifuged $(10 \mathrm{~min}$ at $2600 \times \mathrm{g})$ and filtered through $0.45-\mu \mathrm{m}$ membrane filters. Analysis $\mathrm{K}$ and $\mathrm{Rb}$ was performed using ICP-SFMS. In addition, total carbon was measured (Leco Trumac $\mathrm{CN}$ analyser).

$\mathrm{pH}\left(\mathrm{H}_{2} \mathrm{O}\right)$ was measured on five occasions during 1987-2001. Deionised water was added to field-moist samples (soil:water volume ratio $=1: 1$ ) from the forest floor ('FH' layer) to $50 \mathrm{~cm}$ depth in the mineral soil.

Weathering losses of K: bulk fine earth

Geochemical composition of the fine earth $(<2 \mathrm{~mm})$ was obtained for ten to twelve soil layers to $100 \mathrm{~cm}$ 
depth sampled in all four control plots in 1989. No data on $\mathrm{Rb}$ were available from this sampling. The total weathering loss of $\mathrm{K}$ was estimated based on concentrations of $\mathrm{K}$ and two putatively immobile reference elements: $\mathrm{Ti}$ and $\mathrm{Zr}$. Based on the equations and terminology of Brimhall et al. (1991), the loss or accumulation during pedogenesis of a mobile element (indexed ' $j$ '; in our case $\mathrm{K}$ ) in a weathered horizon can be expressed as:

$m_{j, \text { flux }}=V_{\mathrm{w}} \rho_{\mathrm{w}} C_{j, \mathrm{w}}-V_{\mathrm{p}} \rho_{\mathrm{p}} C_{j, \mathrm{p}}$

A positive $m_{j, \text { flux }}$ indicates accumulation of the $j$ th element; negative values indicate loss. $V_{\mathrm{w}}$ and $V_{\mathrm{p}}$ denote the volume of the studied horizon after weathering and under pre-weathering ('protolithic') conditions, respectively; $\rho_{\mathrm{w}}$ and $\rho_{\mathrm{p}}$ are the corresponding dry bulk densities, and $C_{j, \mathrm{w}}$ and $C_{j, \mathrm{p}}$ the element concentration after and before weathering. The volume (thickness) of the horizon as it was before weathering, $V_{\mathrm{p}}$, can be derived from Eq. (1) by measurements of the immobile reference element ( $\mathrm{Ti}$ or $\mathrm{Zr}$; indexed ' $i$ '), for which it is assumed that neither loss nor accumulation in the horizon has occurred:

$m_{i, \text { flux }}=V_{\mathrm{w}} \rho_{\mathrm{w}} C_{i, \mathrm{w}}-V_{\mathrm{p}} \rho_{\mathrm{p}} C_{i, \mathrm{p}}=0$

Rearrangement of Eq. (2) yields the ratio of horizon volume (thickness) after and before weathering:

$\frac{V_{\mathrm{w}}}{V_{\mathrm{p}}}=\frac{\rho_{p} C_{i, \mathrm{p}}}{\rho_{\mathrm{w}} C_{i, \mathrm{w}}}$

Brimhall et al. (1987) demonstrated that the righthand side of Eq. (3) is a 'strainometer' that accounts for changes in average grain density and porosity occurring when minerals of mobile elements are depleted from or added to the investigated horizon during pedogenesis. It also includes any collapse (reduction in bulk volume), that may result from weathering loss of materials from a soil layer, or dilation occurring, for instance, when intrusion of roots and incorporation of organic matter lead to an increase in the volume. Using Eq. (3) to eliminate $V_{\mathrm{p}}$ of Eq. (1) yields the operating equation, by which to estimate losses of a mobile element from a weathered soil horizon:

$m_{j, \text { flux }}=\rho_{\mathrm{w}} V_{\mathrm{w}}\left(C_{j, \mathrm{w}}-C_{j, \mathrm{p}} \frac{C_{i, \mathrm{w}}}{C_{i, \mathrm{p}}}\right)$
Equation (4) is equivalent to the procedure applied by Olsson and Melkerud (1989, 2000), Olsson et al. (1993) and Stendahl et al. (2013) to estimate Holocene elemental losses in Nordic forest soils. In practical work, horizon thickness is used instead of $V_{\mathrm{w}}$, to yield a surface-related elemental flux (e.g., $\mathrm{kg} \mathrm{ha}^{-1}$ ), and the overall loss of the $j$ th element from the soil profile is obtained by summing the results of Eq. (4) over all soil layers that are affected by weathering. Based on the assumption of a homogeneous parent material, the pre-weathering concentrations, $C_{j, \mathrm{p}}$ and $C_{i, \mathrm{p}}$, are obtained from reference materials that are assumed to be unaffected by weathering. In work on Quaternary glacial till, such concentrations are generally assumed to prevail in samples from the $\mathrm{C}$ horizon.

At Skogaby, vertical gradients of zirconium ( $\mathrm{Zr}$ ) and titanium (Ti) (see Results section) suggested that the layers within $0-70 \mathrm{~cm}$ depth were substantially weathered, whereas the deeper layers were little affected. Therefore, losses of $\mathrm{K}$ were calculated for this depth interval in each plot, using the average concentrations over the three sampled depths between 70 and $100 \mathrm{~cm}$ in the relevant plot for estimates of $C_{j, \mathrm{p}}$ and $C_{i, \mathrm{p}}$ in Eq. (4). The calculation was performed both with $\mathrm{Ti}$ and $\mathrm{Zr}$ as the immobile reference. The mass of fine earth was estimated layer by layer in the four control plots in 1989, when soil density and the content of stones and boulders were assessed to $50 \mathrm{~cm}$ depth (Simonsson et al. 2015); for 50-100 cm depth, an average over the four plots for the mass of 40-50 $\mathrm{cm}$ was used as an estimate.

In the samples from 1999, bulk concentrations of K and $\mathrm{Rb}$ were analysed in fine earth $(<2 \mathrm{~mm})$ from four depths $(0-5,30-40,60-70$ and $90-100 \mathrm{~cm})$ within the plots (C3, C24, NS7 and NS19) selected for the present investigation. The elements were analysed with ICP-SFMS after fusing $0.1 \mathrm{~g}$ sample with $0.4 \mathrm{~g}$ $\mathrm{LiBO}_{2}$ and dissolving the product in $\mathrm{HNO}_{3}$ (ALS Environmental in Luleå, Sweden; method modified from EPA 200.8).

Weathering losses of $\mathrm{K}: 2: 1$ minerals

The loss of $\mathrm{K}$ from 2:1 minerals was calculated as the difference between pre-weathering and present $\mathrm{K}$ in interlayers of these minerals found in the weathered zone, 0-70 cm. Due to the low clay content of the soil, the determination of individual 2:1 minerals was 
uncertain. Therefore, the estimates described in the following were based on the overall concentration of 2:1 minerals, which was considered to be measured with sufficient accuracy.

For the pre-weathering content of $\mathrm{K}$ in 2:1 minerals, one estimate was obtained assuming that all present 2:1 minerals, as quantified in the samples from 1999, were derived from micaceous phases with one $\mathrm{K}^{+}$ion per formula unit; 2:1 minerals fitted to the X-ray diffraction patterns, and their formula weights, are shown in Table 2. Because it was assumed that the overall molar amount of 2:1 minerals had remained unchanged in every horizon since formation of the till, this calculation will be referred to as the 'transformation scenario', involving loss of $\mathrm{K}$ from mica precursors, but no formation or dissolution of the 2:1 layers. Another estimate was obtained in a 'neoformation scenario', based on the assumption that the current overall concentration of $2: 1$ minerals in the reference horizons, $70-100 \mathrm{~cm}$, prevailed in the whole profile before the onset of weathering. As in the transformation scenario, it was furthermore assumed that these minerals were entirely micaceous, with one $\mathrm{K}^{+}$ion per formula unit. However, in the neoformation scenario, the pre-weathering masses of these phases were estimated adjusting for soil losses, by multiplying the fine earth mass of each soil layer with a $C_{i, \mathrm{w}} / C_{i, \mathrm{p}}$ ratio (cf. Eq. (4)) for Ti (average for the relevant depth over the four control plots investigated in 1989).

The present interlayer $\mathrm{K}$ of 2:1 minerals in the profile was estimated based on $\mathrm{K}_{\mathrm{HCl}}, \mathrm{K} / \mathrm{Rb}$ ratios in different extracts and the total content of $\mathrm{K}$ in 2:1 minerals according to the analysis of the bulk fine earth mineralogy. It was assumed that $\mathrm{K}_{\mathrm{HCl}}$ can be described as a generalised proportion $(a)$ of the total $\mathrm{K}$ in 2:1 minerals $\left(\mathrm{K}_{2: 1}\right)$ plus a constant contribution (b) from $\mathrm{K}$ feldspars:

$\mathrm{K}_{\mathrm{HCl}}=a \mathrm{~K}_{2: 1}+b$

A range of $\mathrm{K}_{\mathrm{HCl}}$ values were calculated for different horizons and summed up for the profile, each based on a pair of plausible values for $a$ and $b$. The value of $b$ was allowed to vary between 80 and $110 \mathrm{mg} \mathrm{kg}^{-1}$. The lower bound was the lower estimated feldspar contribution in $\mathrm{HCl}$ extracts of a soil (Högåsa) investigated by Andrist-Rangel et al. (2013), which was similar to Skogaby concerning texture and K feldspar content. The upper bound of $b$ was the maximum value that would yield $\mathrm{K} / \mathrm{Rb}$ ratios compatible with those observed in $\mathrm{HCl}$ extracts from 90 to $100 \mathrm{~cm}$ depth among the plots of the present study; bulk concentrations of the two elements was used as an estimate of $\mathrm{K} / \mathrm{Rb}$ in $\mathrm{K}$ feldspar (poor in $\mathrm{Rb}$ on a relative basis), and concentrations in NaTPB extracts as an estimate of $\mathrm{K} / \mathrm{Rb}$ in interlayers of $2: 1$ minerals (rich in $\mathrm{Rb}$ ). Finally, the value of $a$ was allowed to vary in the range $0.14-0.22$. Based on the mineralogy of the reference horizons, values $<0.14$ were ruled out because they would imply that more K was present in 2:1 minerals than could be there, even if all 2:1 minerals were micaceous with one $\mathrm{K}^{+}$ion per formula unit. The upper value was the coefficient reported for 'clays' by Andrist-Rangel et al. (2013); these soils had a greater proportion of their interlayer $\mathrm{K}$ extracted by $2 \mathrm{M} \mathrm{HCl}$ than 'sands and tills', and hence the coefficient for Skogaby was unlikely to exceed this value.

\section{$\mathrm{K}$ and $\mathrm{Rb}$ in biomass and litter}

The biomass of all tree compartments above and below ground was derived from stem diameter measurements and allometric functions (see Simonsson et al. 2015). The pools of $K$ accumulated in the biomass relied on analyses performed in 2001 in all above-ground biomass compartments after digestion with concentrated $\mathrm{HNO}_{3}$ and $\mathrm{HClO}_{4}$ (volume-tovolume ratio of the acids, 10:1). For the stump and root compartment, it was assumed that the concentration equalled the mass-weighted average concentration in stem wood and stem bark. In addition, $\mathrm{K}$ and $\mathrm{Rb}$ in needles, stem bark, stem wood, needle litter and humus were analysed in 2014 using ICP-SFMS (modified from EPA 200.8) after applying the same digestion method as in 2001. The pools of $\mathrm{Rb}$ were calculated combining $\mathrm{K} / \mathrm{Rb}$ ratios, as analysed in 2014, with the K pools determined in 2001. Pools of $\mathrm{Rb}$ in living and dead branches (not analysed in 2014) were estimated from the pool of $\mathrm{K}$ in the same compartments and a generalised average $\mathrm{K} / \mathrm{Rb}$ ratio based on all other above-ground tree compartments.

Fluxes of $\mathrm{K}$ between soil and vegetation

The trees' gross uptake of $\mathrm{K}$ from forest floor and mineral soil was estimated by Simonsson et al. (2015). The efflux of $\mathrm{K}$ from the forest floor to the mineral soil was measured in zero-tension humus lysimeter 
leachates collected at the bottom of the forest floor. One such lysimeter was installed in each of the plots C24 and NS19 in June 1992. They were made of polyethylene Büchner funnels with an inner diameter of $13 \mathrm{~cm}$ and edges cut down to a height of $5 \mathrm{~mm}$, allowing roots to grow into the sampled volume of humus. The funnel was connected via a PVC tube leading to the bottom of a 1000-ml collection bottle (also PVC) placed in a pit at a level below the funnel. Upon installation, a core extending to the bottom of the humus layer was cut out from the forest floor and put back onto the lysimeter. Depending on the hydrological conditions, seepages were collected 2-8 times per year from July 1992 to October 1998. Data on sample volume and $\mathrm{K}$ concentrations, analysed by inductively coupled plasma atomic emission spectroscopy (ICP-AES), were combined on an annual basis and related to the area covered by the lysimeter, to yield an efflux of $\mathrm{K}, \mathrm{kg} \mathrm{ha}^{-1} \mathrm{year}^{-1}$. Data from the first two years were disregarded, when the decay of roots cut off during the installation caused abnormally high concentrations of dissolved ions.

\section{A fractionation model for fluxes of $\mathrm{K}$ and $\mathrm{Rb}$ between vegetation and mineral soil}

A fractionation model was developed that described the possible discrimination against, or preference for, $\mathrm{Rb}$ in the cycling of $\mathrm{K}$. In line with the practice in work on stable isotopes, where ratios are formulated to express the relative abundance of the minority species, the ratio of $\mathrm{Rb} / \mathrm{K}$ was used rather than the inverse. However, we used weight rather than molar ratios, to facilitate comparison with the literature on $\mathrm{K}$ and $\mathrm{Rb}$ in plants and minerals. Because each of the two fractionation factors (denoted ' $\alpha$ ' below) describes the relation of two ratios, they would have the same numerical value if molar ratios were used instead.The biomass (tree compartments above and below ground) and forest floor (litter and humus) were lumped together into a 'biopool' compartment, as opposed to the mineral soil. Fractionation was estimated for the leaching from the biopool into the mineral soil, and for the uptake by roots from the mineral soil. The variables used in the model are listed in Table 3. We first define a fractionation factor for the leaching,

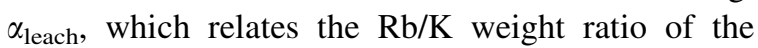
leaching fluxes $\left(R_{\text {leach }}\right)$ with the corresponding ratio in the biopool $\left(R_{\mathrm{bio}}\right)$ :
$R_{\text {leach }}=\frac{\phi_{\mathrm{Rb}, \text { leach }}}{\phi_{\mathrm{K}, \text { leach }}}=\alpha_{\text {leach }} R_{\mathrm{bio}}$

Next, we assume that the exchange complex at $0-5 \mathrm{~cm}$ depth, as observed in the samples from 1999, was in equilibrium with the water leaching from the biopool. $R_{\text {leach }}$ is therefore related to the $\mathrm{Rb} / \mathrm{K}$ weight ratio on the cation exchanger at $0-5 \mathrm{~cm}$ depth $\left(R_{\mathrm{ex}}, 0-5 \mathrm{~cm}\right)$ by Eq. (7):

$R_{\text {leach }}=\frac{R_{\mathrm{ex}, 0-5 \mathrm{~cm}}}{k_{\mathrm{Rb} / \mathrm{K}}}$

In Eq. (7), $k_{\mathrm{Rb} / \mathrm{K}}$ is the selectivity coefficient for $\mathrm{Rb} / \mathrm{K}$ exchange in the soil, defined in terms of solute concentrations, $\left[\mathrm{K}^{+}\right]$and $\left[\mathrm{Rb}^{+}\right]$, and their equivalent fractions on the cation exchanger, $E_{\mathrm{K}}$ and $E_{\mathrm{Rb}}$ :

$k_{\mathrm{Rb} / \mathrm{K}}=\frac{\left[\mathrm{K}^{+}\right] E_{\mathrm{Rb}}}{\left[\mathrm{Rb}^{+}\right] E_{\mathrm{K}}}$

Although $k_{\mathrm{Rb} / \mathrm{K}}$ is based on molar and equivalent quantities, its numerical value is not changed when using weight ratios in the solution and on the cation exchanger. This is because both cations have the same charge and, therefore, unity stoichiometric coefficients upon mutual cation exchange. The fractionation factor $\alpha_{\text {leach }}$ can be derived by combining Eqs. (6) and (7) and inserting current data for $R_{\mathrm{bio}}$ and $R_{\mathrm{ex}}, 0-5 \mathrm{~cm}$ together with published $k_{\mathrm{Rb}}$ / K values:

$\alpha_{\text {leach }}=\frac{R_{\mathrm{ex}, 0-5 \mathrm{~cm}}}{k_{\mathrm{Rb} / \mathrm{K}} R_{\mathrm{bio}}}$

Similarly, a fractionation factor $\left(\alpha_{\text {uptake }}\right)$, for the vegetation's uptake of $\mathrm{K}$ and $\mathrm{Rb}$ from the mineral soil, is defined such that the uptake rate for $\mathrm{Rb}$ $\left(\phi_{\mathrm{Rb} \text {,uptake }}\right)$ is obtained from $\phi_{\mathrm{K}}$, uptake and the average $\mathrm{Rb} / \mathrm{K}$ ratio in the root zone $\left(R_{\mathrm{ex}, z}\right)$ :

$\phi_{\mathrm{Rb}, \text { uptake }}=\alpha_{\text {uptake }} R_{\mathrm{ex}, z} \phi_{\mathrm{K}, \text { uptake }}$

For comparison with solution-based estimates from the literature, conversion into a fractionation factor in regard to the weight ratio of $\mathrm{Rb}$ and $\mathrm{K}$ in the soil solution can be derived using Eq. (8):

$\alpha_{\text {uptake }}^{\prime}=k_{\mathrm{Rb} / \mathrm{K}} \alpha_{\text {uptake }}$

During the model evaluation, conditions for preferential cycling of K were tested. Such preference might 
Table 3 Variables in the fractionation model used to assess the preference for $\mathrm{K}$ or $\mathrm{Rb}$ in the fluxes of uptake from and leaching into the mineral soil

\begin{tabular}{|c|c|c|c|}
\hline Variable & Definition & Variable & Definition \\
\hline $\mathrm{K}_{\text {bio }}, \mathrm{Rb}_{\text {bio }}$ & $\begin{array}{l}\text { Pools of } \mathrm{K}(\mathrm{Rb}) \text { in the 'biopool'; i.e., the sum of } \\
\text { biomass (trees, above and below ground), } \\
\text { litter and humus (forest floor); } \mathrm{kg} \mathrm{ha}^{-1}\end{array}$ & $R_{\text {bio }}$ & $\mathrm{Rb} / \mathrm{K}$ weight ratio in the biopool, $\mathrm{Rb}_{\text {bio }} / \mathrm{K}_{\text {bio }}$ \\
\hline$\phi_{\mathrm{K}, \mathrm{dep}}, \phi_{\mathrm{Rb}, \mathrm{dep}}$ & $\begin{array}{l}\text { Input flux of } \mathrm{K}(\mathrm{Rb}) \text { to the ecosystem by } \\
\text { deposition; } \mathrm{kg} \mathrm{ha}^{-1} \text { year }^{-1}\end{array}$ & $R_{\text {leach }}$ & $\begin{array}{l}\mathrm{Rb} / \mathrm{K} \text { weight ratio in the flux of leaching into } \\
\text { the mineral soil, } \phi_{\mathrm{Rb}} \text {, leach } / \phi_{\mathrm{K}} \text {, leach }\end{array}$ \\
\hline$\phi_{\mathrm{K}, \text { leach }}, \phi_{\mathrm{Rb} \text {, leach }}$ & $\begin{array}{l}\text { Leaching flux of } \mathrm{K}(\mathrm{Rb}) \text { from the biopool into } \\
\text { the mineral soil; } \mathrm{kg} \mathrm{ha}^{-1} \text { year }^{-1}\end{array}$ & $R_{\mathrm{ex}, 0-5 \mathrm{~cm}}$ & $\begin{array}{l}\mathrm{Rb} / \mathrm{K} \text { weight ratio of exchangeable cations } \\
\text { within } 0-5 \mathrm{~cm} \text { depth of the mineral soil }\end{array}$ \\
\hline$\phi_{\mathrm{K} \text {, uptake }}, \phi_{\mathrm{Rb}}$, uptake & $\begin{array}{l}\text { Uptake flux of } \mathrm{K}(\mathrm{Rb}) \text { by the trees, includes } \\
\text { only the portion derived from the mineral soil; } \\
\mathrm{kg} \mathrm{ha}^{-1} \text { year }^{-1}\end{array}$ & $R_{\mathrm{ex}, z}$ & $\begin{array}{l}\mathrm{Rb} / \mathrm{K} \text { weight ratio of exchangeable cations in } \\
\text { the root zone, weighted average over } \\
0-100 \mathrm{~cm} \text { depth of the mineral soil, weights } \\
\text { according to relative root distribution in the } \\
\text { profile }\end{array}$ \\
\hline$\left[\mathrm{K}^{+}\right],\left[\mathrm{Rb}^{+}\right]$ & 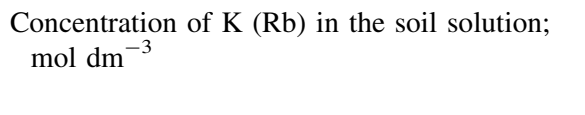 & $\alpha_{\text {leach }}$ & $\begin{array}{l}\text { Fractionation factor for leaching from the } \\
\text { biopool into the mineral soil, } R_{\text {leach }} / R_{\text {bio }} \text {; } \\
\text { dimensionless }\end{array}$ \\
\hline$E_{\mathrm{K}}, E_{\mathrm{Rb}}$ & $\begin{array}{l}\text { Equivalent fractions of exchangeable } \mathrm{K}(\mathrm{Rb}) \text {; } \\
\text { i.e., exchangeable } \mathrm{K}(\mathrm{Rb}) \text { divided by the } \\
\text { cation exchange capacity; } \operatorname{mol}_{\mathrm{c}} \mathrm{mol}_{\mathrm{c}}^{-1}\end{array}$ & $\alpha_{\text {uptake }}$ & $\begin{array}{l}\text { Fractionation factor for uptake from the } \\
\text { mineral soil relative to exchangeable } \mathrm{Rb} \text { and } \\
\mathrm{K} \text { in the root zone (' } z \text { '), } \\
\left(\phi_{\mathrm{Rb} \text {, uptake }} / \phi_{\mathrm{K} \text {, uptake }}\right) \times R_{\mathrm{ex}, z}^{-1} \text {; dimensionless }\end{array}$ \\
\hline$k_{\mathrm{Rb} / \mathrm{K}}$ & $\begin{array}{l}\text { Selectivity coefficient for cation exchange in } \\
\text { the soil }\left(\mathrm{Rb}^{+} \text {bound, } \mathrm{K}^{+} \text {released); }\right. \\
\text { dimensionless }\end{array}$ & $\alpha_{\text {uptake }}^{\prime}$ & $\begin{array}{l}\text { Fractionation factor for uptake from the } \\
\text { mineral soil relative to } \mathrm{Rb} \text { and } \mathrm{K} \text { in the soil } \\
\text { solution of the root zone, } \\
\left(\phi_{\mathrm{Rb}} \text {, uptake } / \phi_{\mathrm{K}} \text {, uptake }\right) \times\left(c_{\mathrm{Rb}} / c_{\mathrm{K}}\right)_{z}^{-1} \text {, where } \\
c_{\mathrm{Rb}} / c_{\mathrm{K}} \text { is the weight ratio of } \mathrm{Rb} \text { and } \mathrm{K} \text { in the } \\
\text { soil solution; dimensionless }\end{array}$ \\
\hline$R_{\mathrm{dep}}$ & $\begin{array}{l}\mathrm{Rb} / \mathrm{K} \text { weight ratio in the deposition flux, } \\
\phi_{\mathrm{Rb}, \mathrm{dep}} / \phi_{\mathrm{K}, \mathrm{dep}}\end{array}$ & $t$ & Time; year \\
\hline
\end{tabular}

occur if the vegetation discriminates against $\mathrm{Rb}$ during uptake, and can be defined either with respect to the exchange complex $\left(\alpha_{\text {uptake }}<1\right)$ or the soil solution $\left(\alpha^{\prime}\right.$ uptake $\left.<1\right)$. However, preferential cycling of $\mathrm{K}$ may also be the result of preferential retention of $\mathrm{Rb}$ in the biopool, resulting in a larger $\mathrm{K} / \mathrm{Rb}$ ratio in the efflux from the biopool than in the uptake into it. According to Eqs. (6) and (10), this will be the case under the following condition:

$\alpha_{\text {uptake }}>\alpha_{\text {leach }} \frac{R_{\text {bio }}}{R_{\text {ex }, z}}$

The corresponding critical $\alpha^{\prime}$ uptake may be obtained by combining Eqs. (9) (11) and (12); it is simply the ratio of $R_{\mathrm{ex}}$ of the uppermost mineral soil and the root-zone as a whole:

$\alpha_{\text {uptake }}^{\prime}>\frac{R_{\mathrm{ex}, 0-5 \mathrm{~cm}}}{R_{\mathrm{ex}, z}}$
To test conditions that would imply changes in $R_{\text {bio }}$, a differential equation is needed. Equation (14) relates the infinitesimal change, $\mathrm{d} R_{\text {bio }}$, to infinitesimal changes in the biopool stocks of $\mathrm{K}$ and $\mathrm{Rb}\left(\mathrm{kg} \mathrm{ha}^{-1}\right)$, from $\left(\mathrm{K}_{\mathrm{bio}}\right)$ to $\left(\mathrm{K}_{\mathrm{bio}}+\mathrm{dK}_{\mathrm{bio}}\right)$ and similarly for $\mathrm{Rb}$ :

$\mathrm{d} R_{\text {bio }}=\frac{\mathrm{dRb}_{\text {bio }}-R_{\text {bio }} \mathrm{dK}_{\text {bio }}}{\mathrm{K}_{\text {bio }}+\mathrm{dK}_{\text {bio }}}$

The differential $\mathrm{dK}_{\mathrm{bio}}$ during time, $\mathrm{d} t$, is related to the inputs of uptake and deposition, and the output of leaching; Eq. (15):

$\mathrm{dK}_{\mathrm{bio}}=\left(\phi_{\mathrm{K}, \text { uptake }}+\phi_{\mathrm{K}, \mathrm{dep}}-\phi_{\mathrm{K}, \text { leach }}\right) \mathrm{d} t$

A corresponding expression for $\mathrm{dRb}_{\text {bio }}$ can be derived using Eqs. (6) (10) and the deposition of $\mathrm{Rb}\left(\phi_{\mathrm{Rb}, \mathrm{dep}}\right)$, which is obtained directly from the $\mathrm{Rb} / \mathrm{K}$ ratio in the deposition $\left(R_{\mathrm{dep}}\right)$ and $\phi_{\mathrm{K}, \mathrm{dep}}$ : 
$\phi_{\mathrm{Rb}, \mathrm{dep}}=R_{\mathrm{dep}} \phi_{\mathrm{K}, \mathrm{dep}}$

The differential for $\mathrm{Rb}_{\text {bio }}$, corresponding to Eq. (15), then becomes:

$$
\begin{aligned}
\mathrm{dRb}_{\mathrm{bio}}= & \left(\alpha_{\text {uptake }} R_{\mathrm{ex}, \mathrm{z}} \phi_{\mathrm{K}, \text { uptate }}+R_{\mathrm{dep}} \phi_{\mathrm{K}, \mathrm{dep}}\right. \\
& \left.-\alpha_{\text {leach }} R_{\mathrm{bio}} \phi_{\mathrm{K}, \text { leach }}\right) \mathrm{d} t
\end{aligned}
$$

For small $\mathrm{d} t$, implying negligible changes in $\mathrm{K}_{\mathrm{bio}}$, substituting Eqs. (15) and (17) into Eq. (14) yields the derivative of $R_{\text {bio }}$ with respect to time:

$$
\begin{aligned}
& \frac{\mathrm{d} R_{\mathrm{bio}}}{\mathrm{d} t}=\frac{1}{K_{\mathrm{bio}}}\left[\left(\alpha_{\text {uptake }} R_{\mathrm{ex}, z}-R_{\mathrm{bio}}\right) \phi_{\mathrm{K}, \text { uptake }}\right. \\
& \left.\quad+\left(R_{\mathrm{dep}}-R_{\mathrm{bio}}\right) \phi_{\mathrm{K}, \mathrm{dep}}+\left(1-\alpha_{\text {leach }}\right) R_{\mathrm{bio}} \phi_{\mathrm{K}, \text { leach }}\right]
\end{aligned}
$$

\section{Results}

Mineralogy of fine earth and clay fraction

The mineralogy at the Skogaby site (Table 4) was dominated by quartz and feldspars, with concentrations that varied very little between the investigated plots. In addition, there were minor contributions of amphiboles (2-3\%), 2:1 minerals (1-4\%) and amorphous Fe oxides (1-2\%). Compared to the bottom of the profiles, amphiboles generally showed a decline and clay minerals an increase in the upper part of the profile. All plots displayed a peak concentration of 2:1 minerals in the B horizon, at a depth of approximately $30 \mathrm{~cm}$, and relatively low concentrations around $10 \mathrm{~cm}$ and at the bottom of the profile, indicating either a degree of stratification in the parent material, or neoformation of 2:1 minerals in the B horizon. Although the full-pattern fitting used a variety of standard clay types, the distinction of expandable versus micaceous types was considered uncertain because of the low concentrations of these minerals. Therefore, the 2:1 minerals are grouped together in Table 4 and Fig. 1.

The qualitative analysis of parallel-orientated clay fractions $(<2 \mu \mathrm{m})$ revealed a vertical gradient in phyllosilicate composition (Fig. 2a). At the top of the mineral soil, vermiculitic clay was preponderant. However, $d$ spacings in glycolated traces were smaller

\begin{tabular}{|c|c|c|c|c|c|c|c|c|}
\hline $\begin{array}{l}\text { Depth } \\
(\mathrm{cm})\end{array}$ & Quartz & $\begin{array}{l}\text { Plagio- } \\
\text { clases }\end{array}$ & $\begin{array}{l}\text { K feld- } \\
\text { spars }\end{array}$ & $\begin{array}{l}\text { Amphi- } \\
\text { boles }\end{array}$ & $\begin{array}{l}\text { Sum of } 2: 1 \\
\text { minerals } \mathrm{s}^{\mathrm{a}}\end{array}$ & Kaolinite & Goethite & $\begin{array}{l}\text { Amorphous Fe } \\
\text { oxides }\end{array}$ \\
\hline $0-5$ & $52 \pm 2$ & $22 \pm 1$ & $19 \pm 1$ & $1.9 \pm 0.4$ & $3.7 \pm 0.6$ & $0.3 \pm 0.2$ & $0.008 \pm 0.016$ & $1.1 \pm 0.4$ \\
\hline $5-10$ & $53 \pm 1$ & $22 \pm 0.3$ & $19 \pm 1$ & $2.1 \pm 0.5$ & $2.3 \pm 0.4$ & $0.01 \pm 0.02$ & n.d. ${ }^{b}$ & $1.3 \pm 0.4$ \\
\hline $10-20$ & $53 \pm 2$ & $22 \pm 1$ & $18 \pm 1$ & $2.5 \pm 0.7$ & $2.4 \pm 0.7$ & $0.3 \pm 0.2$ & n.d. & $1.8 \pm 0.5$ \\
\hline $20-30$ & $50 \pm 2$ & $23 \pm 1$ & $19 \pm 0.4$ & $3 \pm 0.8$ & $3.2 \pm 0.5$ & $0.1 \pm 0.1$ & n.d. & $2.1 \pm 0.3$ \\
\hline $30-40$ & $46 \pm 2$ & $24 \pm 1$ & $19 \pm 0.4$ & $3.8 \pm 0.5$ & $4.4 \pm 1.0$ & $0.3 \pm 0.3$ & n.d. & $2.5 \pm 0.7$ \\
\hline $40-50$ & $49 \pm 1$ & $25 \pm 1$ & $19 \pm 1$ & $3.7 \pm 0.2$ & $2.7 \pm 0.7$ & n.d. & n.d. & $1.7 \pm 0.4$ \\
\hline $50-60$ & $49 \pm 2$ & $25 \pm 0.5$ & $19 \pm 0.5$ & $3.5 \pm 0.6$ & $1.9 \pm 0.3$ & n.d. & n.d. & $1.3 \pm 0.2$ \\
\hline $60-70$ & $50 \pm 2$ & $25 \pm 1$ & $19 \pm 1$ & $3.2 \pm 0.3$ & $1.4 \pm 0.3$ & n.d. & n.d. & $1.1 \pm 0.2$ \\
\hline $70-80$ & $51 \pm 1$ & $25 \pm 1$ & $19 \pm 0.4$ & $3.2 \pm 0.4$ & $1.3 \pm 0.2$ & n.d. & n.d. & $0.9 \pm 0.1$ \\
\hline $80-90$ & $51 \pm 2$ & $25 \pm 1$ & $19 \pm 1$ & $3.2 \pm 0.4$ & $1.4 \pm 0.3$ & n.d. & n.d. & $1.1 \pm 0.1$ \\
\hline $90-100$ & $51 \pm 1$ & $25 \pm 0.5$ & $19 \pm 0.5$ & $3.1 \pm 0.5$ & $1.1 \pm 0.1$ & n.d. & n.d. & $1.0 \pm 0.1$ \\
\hline
\end{tabular}
$(13.6-13.9$ A) than normally recorded for

Table 4 Composition of the mineral soil according to quantitative mineralogical analysis performed on samples from 1999, means and 2 standard errors over four plots (C3, C24, NS7 and NS19), percentages of fine earth $(<2 \mathrm{~mm})$

Percent weight of identified mineral phases, average over four plots \pm 2 standard errors

The percentages in each row sum up to $100 \%$ and therefore are equivalent to concentrations in the non-organic compartment of the soil

a Sum of the following phases in Table 2: muscovite, biotite, phlogopite, hydrobiotite, vermiculite and smectite

b Not detected 


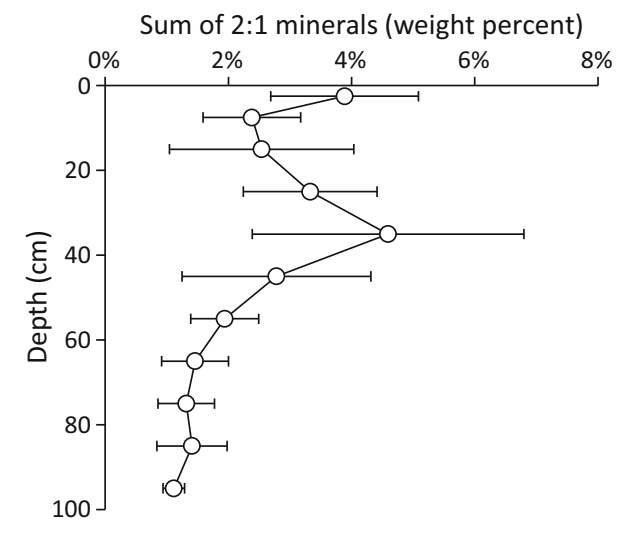

Fig. 1 Sum of 2:1 minerals detected by the quantitative mineralogical analysis of the bulk fine earth (cf. Table 2). Average (dots) and 2 standard errors (bars) over four plots

vermiculites, and asymmetry towards $10 \AA$ was present, both features suggesting that interstratified micaceous layers were present in the vermiculitic clay.

From 10 to $50 \mathrm{~cm}$ depth $(30-40 \mathrm{~cm}$ shown in Fig. 2a), resistance to collapse upon heating to $300{ }^{\circ} \mathrm{C}$ indicated the presence of a significant hydroxideinterlayered component, with high-angle (low $d$ spacing) asymmetry indicating the presence of micaceous layers as in the uppermost soil.

Below the B horizon, at approximately $60 \mathrm{~cm}$ and downwards (80-90 cm shown in Fig. 2a), a regularly interstratified mica/vermiculite component with a peak near $12 \AA$ was apparent (corresponding to 'hydrobiotite' in the bulk mineralogical analysis), along with peaks at 14 and $10 \AA$ that indicated the presence of discrete vermiculite and mica.

Treatment of the clay fractions with $6 \mathrm{M} \mathrm{HCl}$ appeared to remove the vermiculite and the mica/ vermiculite components from the 80-90-cm sample, indicating their probable trioctahedral nature (Fig. 2b). In contrast, the vermiculitic mineral in the shallow part of the profile (samples from 0 to $5 \mathrm{~cm}$ and $30-40 \mathrm{~cm}$ ) was unaffected by the acid treatment, indicating its decahedral nature. The generally enhanced intensity in Fig. 2b is a side effect of the $\mathrm{HCl}$ treatment, which by removal of some amorphous materials (oxides and organic matter) results in enhanced orientation on the specimen substrate.
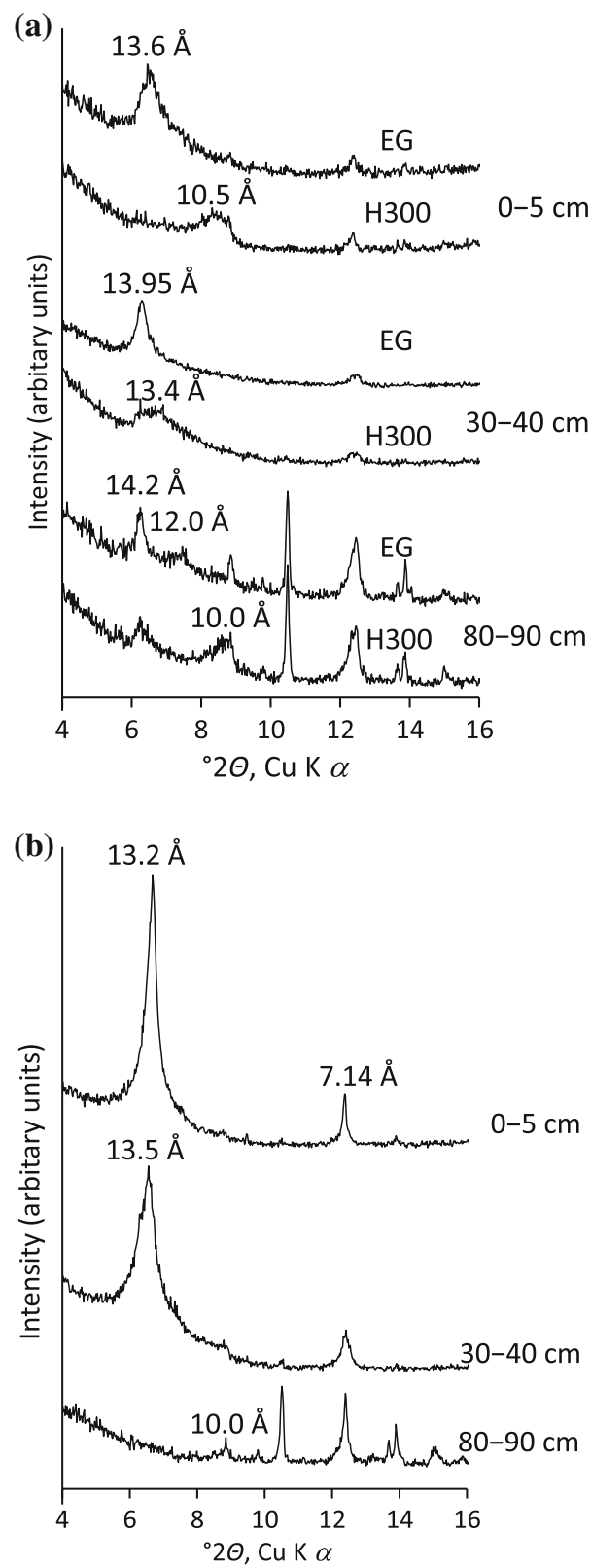

Fig. 2 X-ray diffraction patterns of parallel-orientated mounts of clay fractions $(<2 \mu \mathrm{m})$ from three soil depths in plot $\mathrm{C} 24$ : $0-5,30-40$ and $80-90 \mathrm{~cm}$. Indicated over the patterns are $d$ spacings corresponding to the centroid of selected peaks. a Patterns obtained after ethylene glycolation ('EG') and heating to $300{ }^{\circ} \mathrm{C}$ ('H300') of mounts of otherwise untreated clay fractions. b Patterns of clay fractions treated with $6 \mathrm{M} \mathrm{HCl}$ to remove trioctahedral phases; the mounts were ethylene glycolated prior to the X-ray diffraction 
$\mathrm{K}$ and $\mathrm{Rb}$ extracted by $\mathrm{HCl}$ and $\mathrm{NaTPB}$

$\mathrm{HCl}$-extractable $\mathrm{K}$ in the mineral soil of Skogaby was in the range $100-300 \mathrm{mg} \mathrm{kg}^{-1}$. For comparison, agricultural soils with $<500 \mathrm{mg} \mathrm{kg}^{-1}$ of $\mathrm{K}_{\mathrm{HCl}}$ belong to the lowest $\mathrm{K}$-storage class on the conventionally used five-graded scale. Nevertheless, the extraction produced reproducible patterns, with $\mathrm{K}_{\mathrm{HCl}}$ showing similar trends with respect to depth in all four investigated plots (Fig. 3). All four plots showed an accumulation of $\mathrm{K}$ in the forest floor and a depletion of $\mathrm{K}$ in most of the investigated mineral soil. Thus, the highest concentration occurred in the humus layer
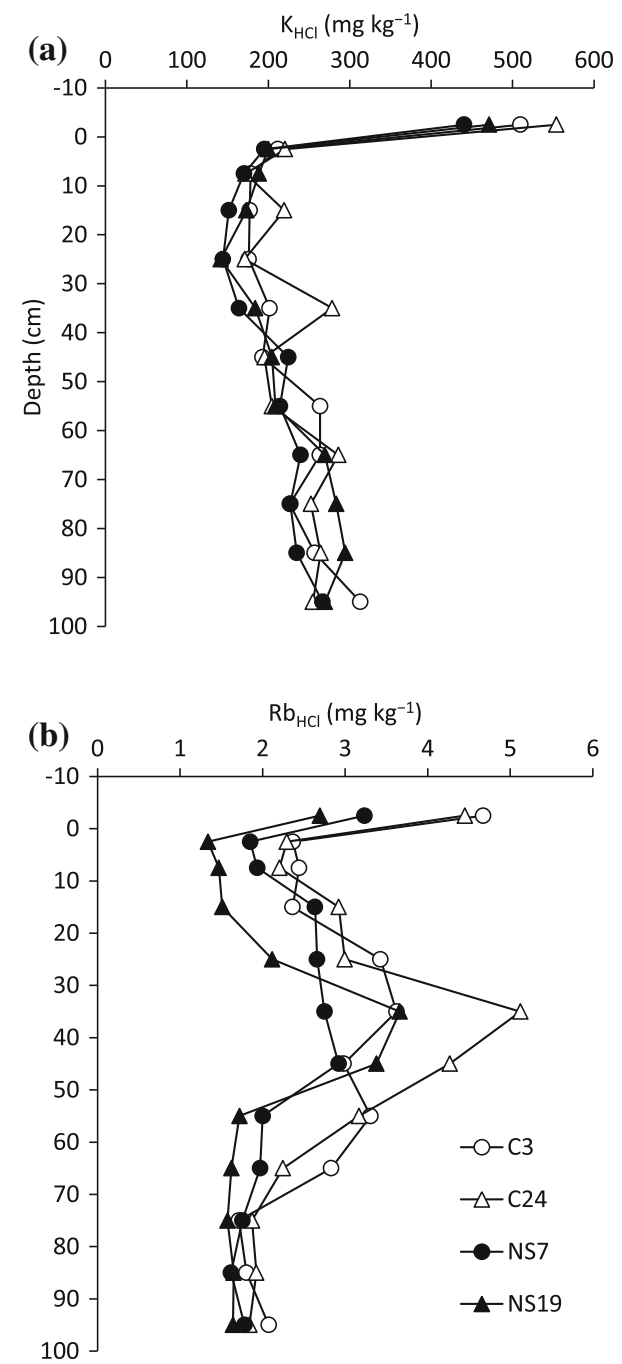

Fig. 3 Depth trend of $\mathrm{HCl}$-extractable $\mathrm{K}$ (a) and $\mathrm{Rb}$ (b) in humus layer (forest floor; negative depth) and the mineral soil $(0-100 \mathrm{~cm})$ in the four investigated plots at the Skogaby site
(500 mg kg$)^{-1}$ ). The concentration showed a minimum of approximately $170 \mathrm{mg} \mathrm{kg}^{-1}$ at $10-30 \mathrm{~cm}$ depth in the mineral soil and then gradually increased towards a value of approximately $270 \mathrm{mg} \mathrm{kg}^{-1}$ at 90-100 cm depth.

Whereas there was no obvious correlation between $\mathrm{K}_{\mathrm{HCl}}$ and the content of various 2:1 minerals, the accumulation of $\mathrm{Rb}_{\mathrm{HCl}}$ was related to the total content of these minerals (Fig. 1). Like for K, there was an accumulation in the humus layer $\left(2.5-4.7 \mathrm{mg} \mathrm{kg}^{-1}\right)$ and a minimum near the top of the mineral soil. However, most striking was an accumulation between 20 and $70 \mathrm{~cm}$ depth in all profiles, with maximum concentrations in the range of $3-5 \mathrm{mg} \mathrm{kg}^{-1}$.

The maximum concentrations obtained by extraction with NaTPB (Fig. 4) were roughly half those obtained with $\mathrm{HCl}$. The concentrations were invariably at the lower extreme of the range obtained by Cox
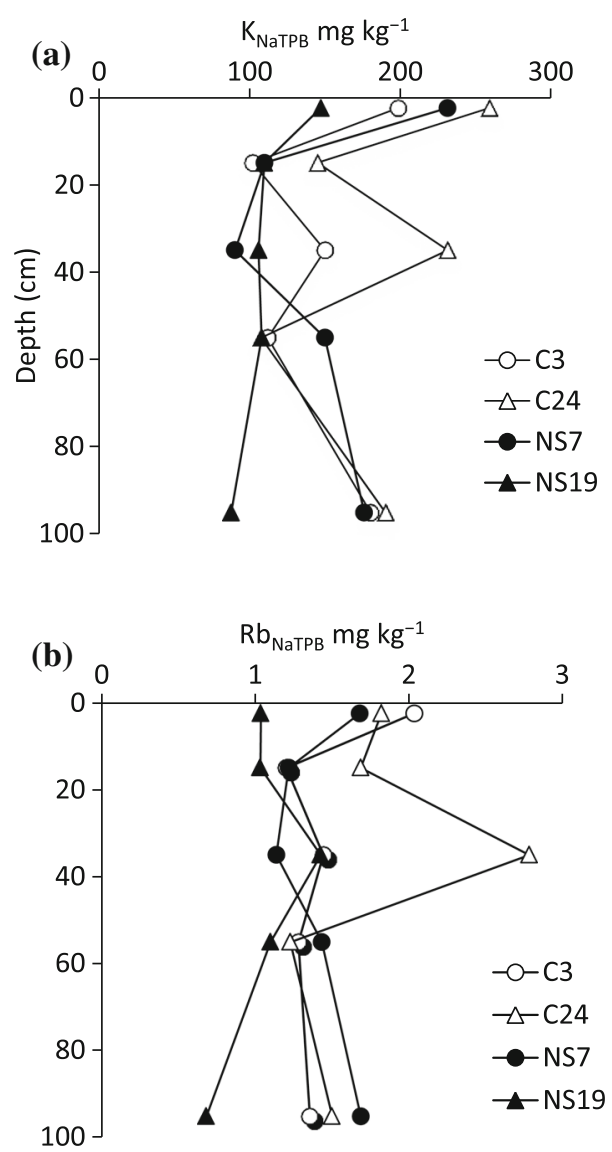

Fig. 4 Depth trend of $\mathrm{K}$ (a) and Rb (b) extracted by sodium tetraphenylborate (NaTPB) in the mineral soil (0-100 cm) in the four investigated plots at the Skogaby site 
et al. (1999), and a kinetic experiment (data not shown) indicated that the extraction had not been brought to completion even after the 15-day incubation used in the present study. For the interpretation of results, the ratio of $\mathrm{K}$ and $\mathrm{Rb}$ obtained by NaTPB extractions was considered more useful than the absolute concentrations.

\section{Exchangeable cations and $\mathrm{pH}$}

Exchangeable K roughly followed the gradient of organic carbon in the profile, although with a somewhat more superficial relative distribution of the former (Fig. 5a, b).
Organic matter is likely to dominate the cation exchange capacity in this profile, low in clay minerals. The depth trend of $\mathrm{Rb}$ (Fig. 5c) differed markedly from that of $\mathrm{K}$, but was similar to the trend of $\mathrm{Rb}_{\mathrm{HCl}}$, with an accumulation at $10-60 \mathrm{~cm}$ (cf. Figure $3 \mathrm{~b}$ ).

Exchangeable $\mathrm{K}$ corresponded to $1-17 \%$ of $\mathrm{K}_{\mathrm{HCl}}$, with the highest value in the uppermost horizons, indicating a lower degree of fixation in clay minerals there (Fig. 5d). For Rb, the exchangeable portion was more constant at $2-4 \%$ of $\mathrm{Rb}_{\mathrm{HCl}}$, with the notable exception of the topmost mineral soil $(0-5 \mathrm{~cm})$ in NS plots, where the exchangeable proportion was similar to that of $\mathrm{K}$.
Fig. 5 Exchangeable (1 M $\left.\mathrm{NH}_{4} \mathrm{Cl}\right) \mathrm{K}(\mathbf{a})$, total carbon (b), exchangeable $\mathrm{Rb}$ (c), proportions of the $\mathrm{HCl}$ extractable $\mathrm{K}(\mathbf{d})$ and $\mathrm{Rb}$ (e) that were exchangeable by $1 \mathrm{M} \mathrm{NH}_{4} \mathrm{Cl}$
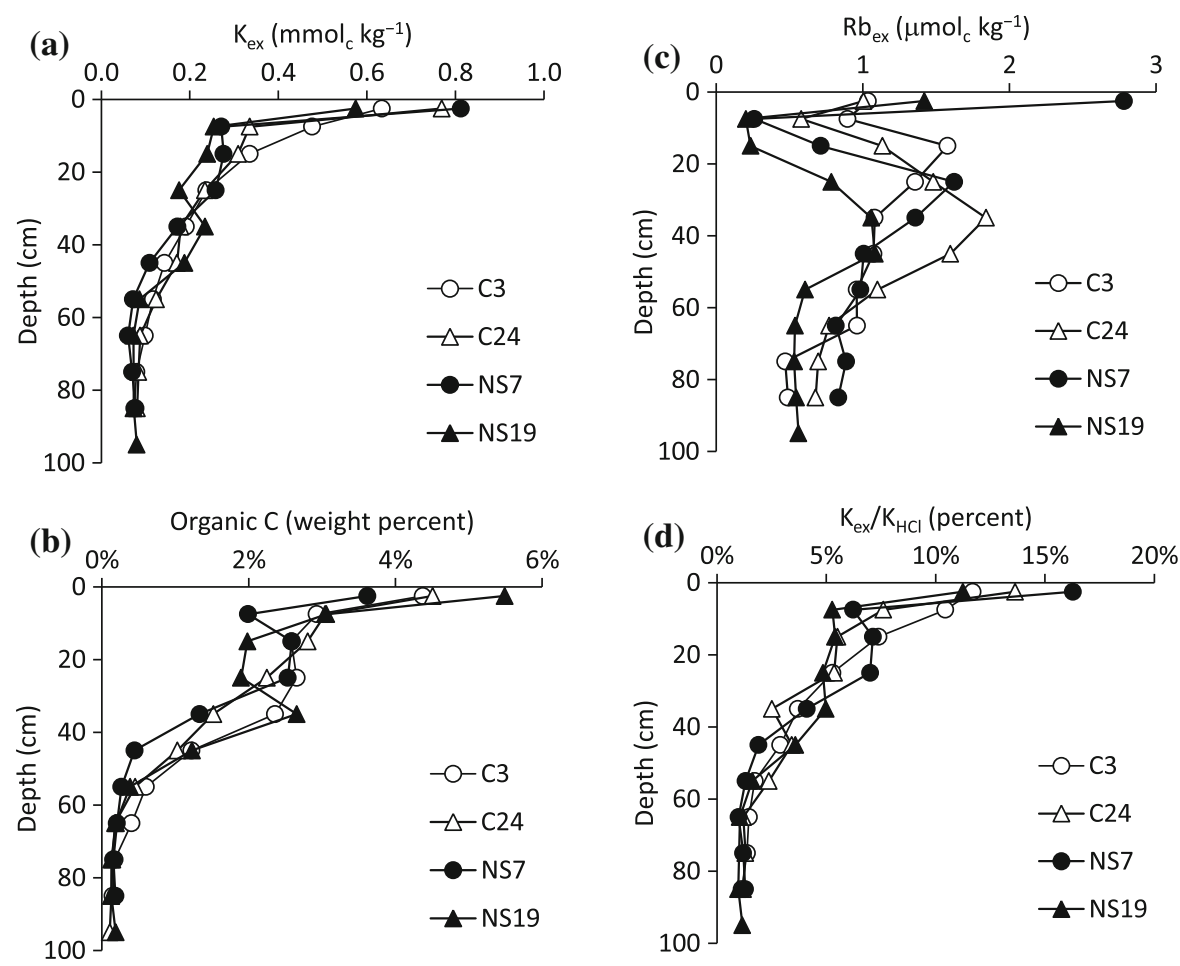

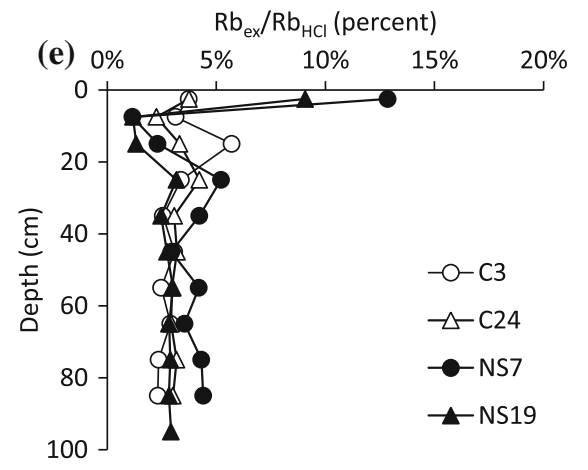


The $\mathrm{pH}$ of the control plots remained similar to the values at the start of the experiment in 1987 (Fig. 6; cf. Table 1). In the NS plots, on the other hand, $\mathrm{pH}$ rapidly declined in the mineral soil during the first six years of the experiment, and then stabilised at values that were $0.3-0.5$ units lower than in the control plots (Fig. 6). The forest floor of NS plots at the same time experienced an increase in $\mathrm{pH}$. The trends in time and space of the remaining control- and NS plots (not shown) were similar to those shown in Fig. 6.

\section{Weathering losses of $\mathrm{K}$}

Bulk concentrations of $\mathrm{K}$ in the samples from 1989 were confined in a narrow range between 2 and $3 \%$ (Fig. 7a), with some variations between plots and horizons but no generally applicable depth trend. Bulk concentrations of the reference elements $\mathrm{Ti}$ and $\mathrm{Zr}$ showed random variations (Fig. 7b, c) and, in addition, general trends of declining concentrations towards greater depth. Losses of $\mathrm{K}$ were calculated for 0-70 cm depth using Eq. (4). An average loss of $22 \mathrm{Mg} \mathrm{ha}^{-1}$ of $\mathrm{K}$ was obtained using either of the two immobile reference elements (Table 5). The result is influenced by random variability in the sampling and analysis of the $\mathrm{Ti}$ and $\mathrm{Zr}$. Even with $\mathrm{Ti}$, which was the reference element showing the more consistent depth trend among plots (Fig. 7b), the calculated losses for individual plots showed a wide range of 9-33 $\mathrm{Mg} \mathrm{ha}{ }^{-1}$; the average should, therefore, be considered as approximate.

According to the mineralogical analysis, feldspars apparently contained more than the overall bulk $\mathrm{K}$ in the soil (Table 5), probably due to heterogeneities

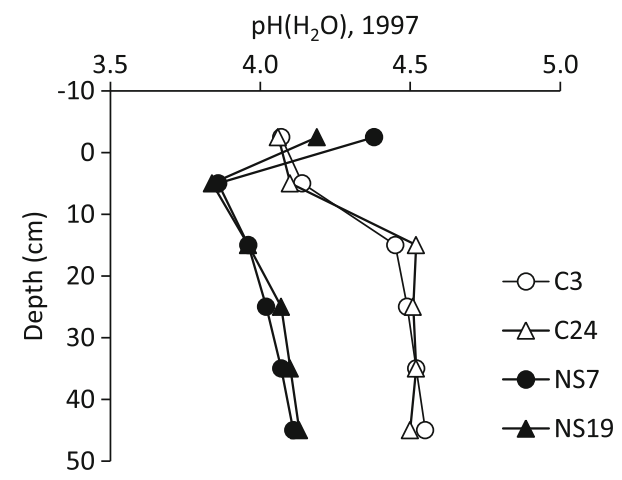

Fig. $6 \mathrm{pH}\left(\mathrm{H}_{2} \mathrm{O}\right)$ as measured in fresh samples in 1997, in the humus layer of the forest floor (negative depth) and mineral soil to $50 \mathrm{~cm}$ depth among the plots sampled in 1989 and 1999. The ensemble of $2: 1$ minerals, as quantified in the mineralogical analysis, contained $8.2-14 \mathrm{Mg} \mathrm{ha}^{-1}$ of $\mathrm{K}$ prior to weathering, according to the 'neoformation' and 'transformation' scenarios described in the Materials and methods section. In the present profile, the estimation range based on mineralogy and $\mathrm{HCl}$
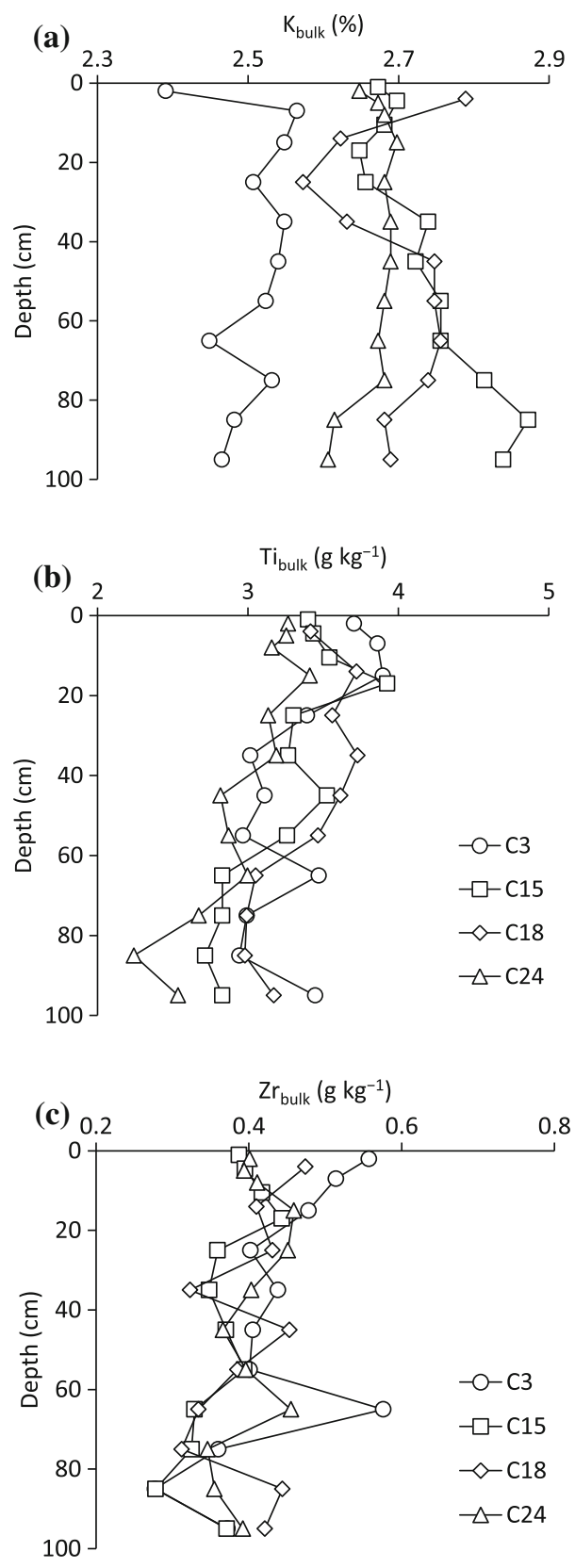

Fig. 7 Depth trends of bulk mineral $\mathrm{K}(\mathbf{a}), \mathrm{Ti}(\mathbf{b})$ and $\mathrm{Zr}$ (c) in four control plots sampled in 1989 (geochemistry) 
Table 5 Pools and changes of $\mathrm{K}$ and $\mathrm{Rb}$ within $0-70 \mathrm{~cm}$ depth. The term 'bulk' denotes concentration according to geochemical analysis

\begin{tabular}{|c|c|c|}
\hline Pool or change in pool & Average & $\begin{array}{l}\text { Standard } \\
\text { error }\end{array}$ \\
\hline Bulk K $\left(\mathrm{Mg} \mathrm{ha}^{-1}\right)^{\mathrm{a}}$ & 121 & 4 \\
\hline $\mathrm{K}$ in feldspars, mineralogical analysis and an idealised formula, $\mathrm{KAlSi}_{3} \mathrm{O}_{8}^{\mathrm{b}}$ & 138 & 1.4 \\
\hline \multicolumn{3}{|l|}{ Total loss of $\mathrm{K}\left(\mathrm{Mg} \mathrm{ha}^{-1}\right)^{\mathrm{a}}$} \\
\hline Ti reference & 22 & 5 \\
\hline $\mathrm{Zr}$ reference & 22 & 9 \\
\hline \multicolumn{3}{|l|}{ Pre-weathering $\mathrm{K}$ in $2: 1$ minerals $^{\mathrm{b}}$} \\
\hline (1) Transformation scenario: all present 2:1 minerals were micaceous, with one $\mathrm{K}^{+}$ion per formula unit & 14 & 0.8 \\
\hline $\begin{array}{l}\text { (2) Neoformation scenario: present concentrations of } 2: 1 \text { minerals in reference horizons prevailed within } \\
0-70 \mathrm{~cm} \text { depth, and were micaceous; correction for soil loss using Ti reference }\end{array}$ & 8.2 & 0.3 \\
\hline \multicolumn{3}{|l|}{ Present $\mathrm{K}$ in $2: 1$ minerals $\left(\mathrm{Mg} \mathrm{ha}^{-1}\right)^{\mathrm{b}}$} \\
\hline (3) Estimated from $\mathrm{K}_{\mathrm{HCl}}, \mathrm{K} / \mathrm{Rb}$ ratios and bulk fine earth mineralogy & $2-4$ & 0.3 \\
\hline \multicolumn{3}{|l|}{ Loss of $\mathrm{K}\left(\mathrm{Mg} \mathrm{ha}^{-1}\right)$ from 2:1 minerals ${ }^{\mathrm{b}}$} \\
\hline (4) Transformation scenario (1-3) & $10-12$ & - \\
\hline (5) Neoformation scenario $(2-3)$ & $4-6$ & - \\
\hline
\end{tabular}

Standard errors express variability between plots only and do not include uncertainties in methods or assumptions

a Value based on bulk geochemistry of the four control plots (C3, C15, C18 and C24) sampled in 1989

b Based on the plots sampled in 1999 (C3, C24, NS7 and NS19)

Table 6 Pools of $\mathrm{K}$ and $\mathrm{Rb}$ in soil and biomass of the four investigated plots in the Skogaby experiment

\begin{tabular}{|c|c|c|c|c|c|c|}
\hline Pool or change in pool & $\mathrm{C} 3$ & $\mathrm{C} 24$ & NS7 & NS19 & Average & Standard error \\
\hline Total $\mathrm{K}$ in tree biomass $\left(\mathrm{kg} \mathrm{ha}^{-1}\right)$ & 150 & 220 & 170 & 250 & 200 & 20 \\
\hline Total $\mathrm{K}$ in litter and humus (forest floor) $\left(\mathrm{kg} \mathrm{ha}^{-1}\right)$ & 30 & 31 & 35 & 33 & 32 & 1 \\
\hline $\mathrm{K}_{\mathrm{ex}}, 0-100 \mathrm{~cm}\left(\mathrm{~kg} \mathrm{ha}^{-1}\right)$ & 51 & 50 & 46 & 50 & 49 & 1 \\
\hline $\mathrm{K}_{\mathrm{HCl}}, 0-100 \mathrm{~cm}\left(\mathrm{~kg} \mathrm{ha}^{-1}\right)$ & 1700 & 1700 & 1400 & 1700 & 1600 & 100 \\
\hline$\Delta \mathrm{K}_{\mathrm{HCl}}, 0-70 \mathrm{~cm}\left(\mathrm{~kg} \mathrm{ha}^{-1}\right)$ & -300 & -180 & -280 & -520 & -320 & 70 \\
\hline Total $\mathrm{Rb}$ in tree biomass $\left(\mathrm{kg} \mathrm{ha}^{-1}\right)$ & 1.0 & 1.2 & 1.3 & 1.9 & 1.4 & 0.2 \\
\hline Total $\mathrm{Rb}$ in litter and humus (forest floor) $\left(\mathrm{kg} \mathrm{ha}^{-1}\right)$ & 0.25 & 0.23 & 0.26 & 0.20 & 0.23 & 0.01 \\
\hline $\mathrm{Rb}_{\mathrm{ex}}, 0-100 \mathrm{~cm}\left(\mathrm{~kg} \mathrm{ha}^{-1}\right)$ & 0.55 & 0.62 & 0.61 & 0.38 & 0.54 & 0.05 \\
\hline $\mathrm{Rb}_{\mathrm{HCl}}, 0-100 \mathrm{~cm}\left(\mathrm{~kg} \mathrm{ha}^{-1}\right)$ & 20 & 21 & 16 & 16 & 18 & 1.3 \\
\hline$\Delta \mathrm{Rb}_{\mathrm{HCl}}, 0-70 \mathrm{~cm}\left(\mathrm{~kg} \mathrm{ha}^{-1}\right)$ & 6.0 & 7.3 & 3.4 & 3.5 & 5.1 & 1.0 \\
\hline$(\mathrm{K} / \mathrm{Rb})_{\text {bio }}$ (biomass + forest floor) $\left(\mathrm{kg} \mathrm{kg}^{-1}\right)$ & 150 & 170 & 130 & 130 & 140 & 10 \\
\hline$(\mathrm{K} / \mathrm{Rb})_{\mathrm{HCl}}$, average $70-100 \mathrm{~cm}\left(\mathrm{~kg} \mathrm{~kg}^{-1}\right)$ & 140 & 140 & 140 & 170 & 150 & 10 \\
\hline$(\mathrm{K} / \mathrm{Rb})_{\text {bulk }}$, average $60-100 \mathrm{~cm}\left(\mathrm{~kg} \mathrm{~kg}^{-1}\right)$ & 380 & 350 & 380 & 380 & 370 & 10 \\
\hline
\end{tabular}

Subscript ' $\mathrm{HCl}$ ' denotes extraction by hot $\left(100^{\circ} \mathrm{C}\right) 2 \mathrm{M} \mathrm{HCl}$; 'ex' means exchangeable cation. The mineral soil was sampled in 1999 ; pools in biomass and humus are based on samples from 2001

extraction data was $2-4 \mathrm{Mg}^{-1}$ of $\mathrm{K}$ in $2: 1$ minerals. The resulting weathering loss of $\mathrm{K}$ from these minerals was $10-12 \mathrm{Mg} \mathrm{ha}^{-1}$ in the transformation scenario, 4-6 $\mathrm{Mg} \mathrm{ha}^{-1}$ in the neoformation scenario.
Pools of $\mathrm{K}$ and $\mathrm{Rb}$ in soil, humus and biomass

Table 6 shows pools of $\mathrm{K}$ and $\mathrm{Rb}$ in the ecosystem at Skogaby. The biomass and humus layer together 
contained 180-280 kg ha ${ }^{-1}$ of $\mathrm{K}$ and $1.3-2.1 \mathrm{~kg} \mathrm{ha}^{-1}$ of $\mathrm{Rb}$. The content of $\mathrm{K}_{\mathrm{HCl}}$ in the mineral soil to $100 \mathrm{~cm}$ depth was of the order of $1.6 \mathrm{Mg} \mathrm{ha}^{-1}$, or 30 times the pool of exchangeable K. Using the average $\mathrm{K}_{\mathrm{HCl}}$ at $70-100 \mathrm{~cm}$ as a reference, the depletion at 0-70 cm (Fig. 3) was in the range of $180-520 \mathrm{~kg} \mathrm{ha}^{-1}$ of $\mathrm{K}\left(\right.$ ' $\Delta \mathrm{K}_{\mathrm{HCl}}$ ' in Table 6); i.e., of a similar order of magnitude as $\mathrm{K}$ in the biomass and representing a small portion of the total $\mathrm{K}$ loss from 2:1 minerals (cf. Table 5). The biomass $\mathrm{K}$ exceeded $\mathrm{K}$ of the forest floor and $\mathrm{K}_{\mathrm{ex}}$ of the mineral soil by a factor of 2-3.

Naturally, all $\mathrm{Rb}$ pools were small compared to those of $\mathrm{K}$. By subtracting the average concentration of $\mathrm{Rb}_{\mathrm{HCl}}$ at 70-100 cm, an apparent accumulation was calculated for $0-70 \mathrm{~cm}$ depth. This ' $\Delta \mathrm{Rb}_{\mathrm{HCl}}$ ' was in the range 3-7 kg ha ${ }^{-1}$ of $\mathrm{Rb}$, which was 2-6 times more than the current pool of $\mathrm{Rb}$ in the biomass.

\section{Relative abundance of $\mathrm{Rb}$ in biomass and soil}

Figure 8 is based on the inverse $K / R b$ ratio, to facilitate the discussion of $\mathrm{Rb}$ as a 'signature' of the $\mathrm{K}$ cycled in the system. Logarithmic $\left(\log _{10}\right)$ values were used, because untransformed ratios would exaggerate differences at high values, and vice versa, and therefore would be sensitive to the arbitrary choice of $\mathrm{K} / \mathrm{Rb}$ or $\mathrm{Rb} / \mathrm{K}$ as the combined variable.

The total concentrations in biomass, litter and humus layer (upper panels of Fig. 8) together with the $\mathrm{HCl}-$ and NaTPB extracts of the soil (lower panels) had $\log _{10}(\mathrm{Rb} / \mathrm{K})$ values ranging from -2.3 to -1.7 , as distinct from the feldspar-dominated mineral bulk value of -2.6 (cf. $\mathrm{K} / \mathrm{Rb}$ ratios in Table 6). The compartments shown in the upper panels will be referred to as 'biopool' compartments. An analysis of variance (ANOVA) over these, with Tukey-adjusted post hoc testing at the $95 \%$ confidence level, indicated that stem bark and humus had somewhat higher $\log _{10}(\mathrm{Rb} / \mathrm{K})$ than needles and litter, while stem wood was intermediate ( $p=0.000$ for compartments). On the average, $\log _{10}(\mathrm{Rb} / \mathrm{K})$ was 0.1 units higher in the biopool NS plots compared to the control plots ( $p=0.002$ for treatments). ANOVA using plot identity, regardless of the treatment, as one factor and sample type as the other (kind of tree organ or the combination of extractant and soil depth) indicated that the litter and humus samples were similar to $\mathrm{HCl}$ extracts from 0 to $10 \mathrm{~cm}$ depth in the soil (lower panels
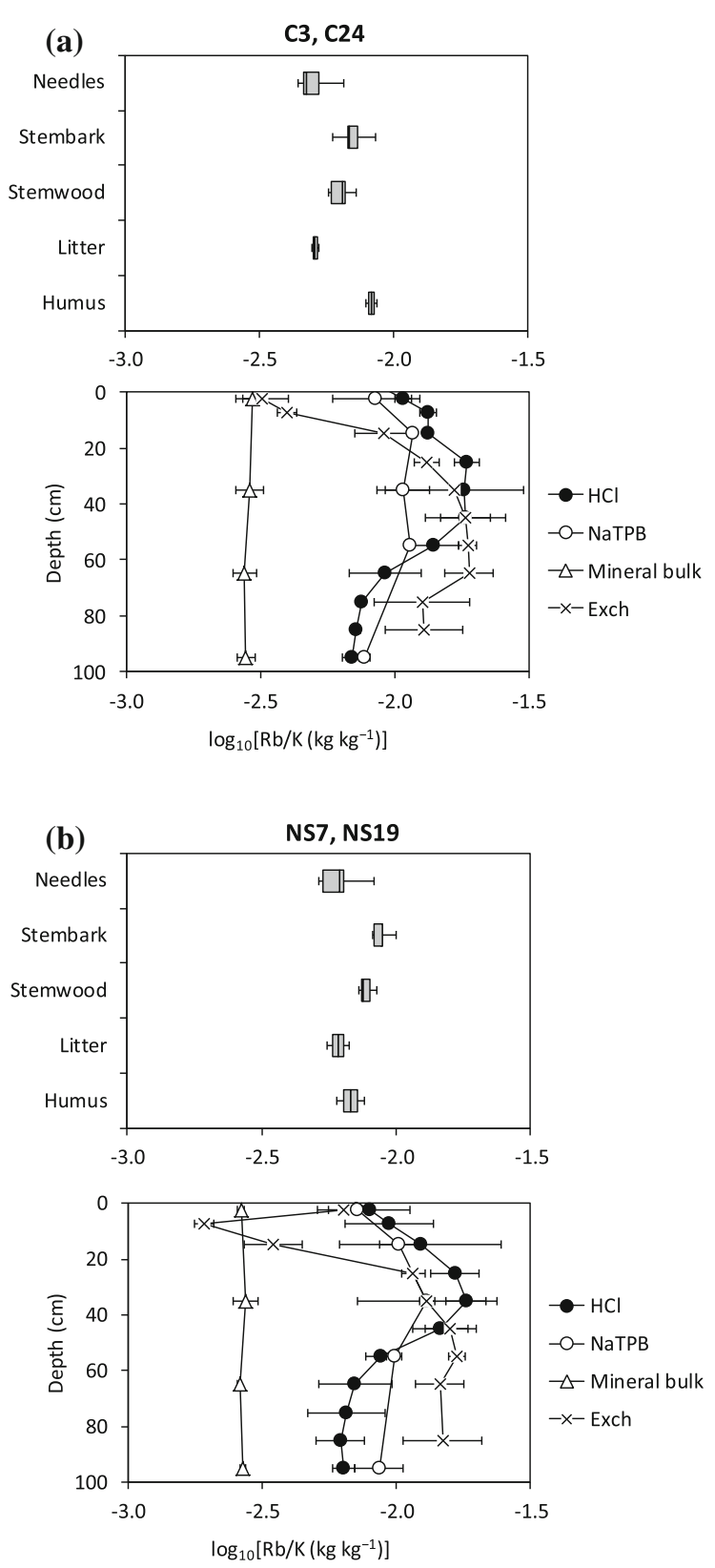

Fig. 8 Upper panels show $\log _{10}(\mathrm{Rb} / \mathrm{K})$ of tree compartments, litter and humus obtained by $\mathrm{HNO}_{3} / \mathrm{HClO}_{4}$ digestion: total data range (whiskers) and quartiles on either side of the median (boxes). Lower panels show $\log _{10}(\mathrm{Rb} / \mathrm{K})$ of the mineral soil extracted with $\mathrm{NH}_{4} \mathrm{Cl}$ (exchangeable cations, 'exch'), hot $\left(100{ }^{\circ} \mathrm{C}\right) 2 \mathrm{M} \mathrm{HCl}$, sodium tetraphenylborate ('NaTPB') and lithium borate fusion ('mineral bulk'): means over two plots, with error bars representing 2 standard errors of the mean. Control plots (a) and ammonium-sulphate treated plots (b)

of Fig. 8), whereas significantly higher $\log _{10}(\mathrm{Rb} / \mathrm{K})$ values were found from 10 to $20 \mathrm{~cm}$ to the maximum around $40 \mathrm{~cm}$ depth. Soil from $60 \mathrm{~cm}$ and deeper was 
similar to the layers from 0 to $10 \mathrm{~cm}$. An analysis of only $\log _{10}(\mathrm{Rb} / \mathrm{K})$ in $\mathrm{HCl}$ extracts from 0 to $100 \mathrm{~cm}$ indicated an effect of treatment $(p=0.001)$, with a $\log _{10}(\mathrm{Rb} / \mathrm{K})$ that on the average was 0.1 lower in the NS plots.

The most obvious effect of the NS treatment in Fig. 8 was observed in exchangeable cations of the topmost mineral soil, $0-5 \mathrm{~cm}$ : The control plots had low $\log _{10}(\mathrm{Rb} / \mathrm{K})$, whereas, in the NS plots, exchangeable cations were similar to the $\mathrm{HCl}$ extracts. At the depth of maximum $\mathrm{Rb}$ accumulation around $40 \mathrm{~cm}$ (Figs. 3b, 5 c), $\log _{10}(\mathrm{Rb} / \mathrm{K}$ ) of exchangeable K (Fig. 8) was similar to that of $\mathrm{K}_{\mathrm{HCl}}$ in both treatments, while at greater depth it was higher.

Humus lysimeter data

In Fig. 9, fluxes of $\mathrm{K}$ from the zero-tension humus lysimeters are presented and compared with throughfall data acquired as described by Simonsson et al. (2015). After the initial flush of $\mathrm{K}$ from decaying roots, $\mathrm{K}$ fluxes from the humus stabilised around $5 \mathrm{~kg} \mathrm{ha}^{-1}$ year $^{-1}$ in plot C24 (average $5.4 \mathrm{~kg} \mathrm{ha}^{-1}$ year $^{-1}$ ). In this plot, the fluxes of $\mathrm{Na}$ and $\mathrm{Cl}$ showed excellent
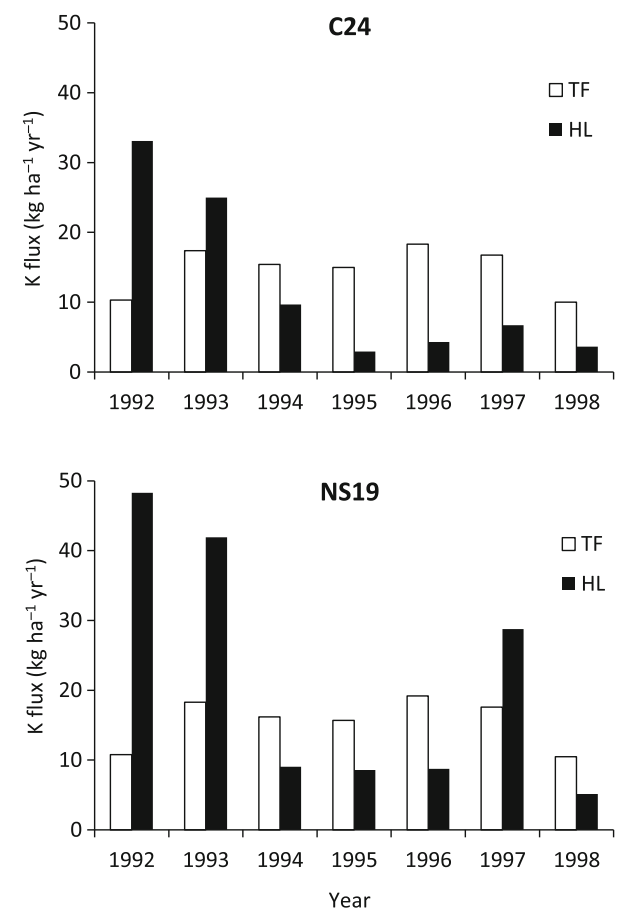

Fig. 9 Annual fluxes of $\mathrm{K}$ from zero-tension humus lysimeters ('HL') compared to throughfall ('TF') in plot C24 and NS19 agreement with throughfall data collected over a larger area in the plots, indicating that the fluxes from the small lysimeters were representative for the plot. In plot NS19, on the other hand, the solutions appeared affected by the repeated applications of ammonium sulphate. It is likely that ion exchange around spots that received grains of ammonium sulphate fertiliser caused a larger efflux of $\mathrm{K}$ with a considerable spatial heterogeneity in time and space; the area covered by the lysimeters was too small to capture the K flux in a representative way in this plot.

Fractionation of $\mathrm{K}$ and $\mathrm{Rb}$ in fluxes between vegetation and mineral soil

The fractionation model outlined in Eqs. (6)-(18) was calibrated using average data of the control plots, for which all necessary fluxes were available. Figure 10 summarises the resulting fractionation factors ( ' $\alpha$ '); shown are also relevant pools and fluxes derived from data of Simonsson et al. (2015). For an explanation of the variables, see Table 3 . The average leaching of $\mathrm{K}$, $\phi_{\mathrm{K}}$, leach $\left(5.4 \mathrm{~kg} \mathrm{ha}^{-1} \mathrm{year}^{-1}\right)$, was obtained for the years 1994-1998 (Fig. 9). A deposition input, $\phi_{\mathrm{K} \text {, dep }}$ $\left(2.7 \mathrm{~kg} \mathrm{ha}^{-1}\right.$ year $\left.^{-1}\right)$, is available from Simonsson et al. (2015). The uptake rate $\left(\phi_{\mathrm{K}}\right.$, uptake, $5.7 \mathrm{~kg} \mathrm{ha}^{-1}$ year $^{-1}$ ) was calculated to match the fluxes of $\phi_{\mathrm{K}}$, leach, $\phi_{\mathrm{K}}$, dep and the pool-change rates in biomass (4.2 $\mathrm{kg} \mathrm{ha}^{-1}$ year $\left.^{-1}\right)$ and forest floor $\left(-1.3 \mathrm{~kg} \mathrm{ha}^{-1}\right.$ year ${ }^{-1}$ ) according to Simonsson et al. (2015). The fluxes at the Skogaby site were characterised by an intense fluxes of $\mathrm{K}$ between the vegetation and the forest floor, and by smaller fluxes to and from the mineral soil. This, together with the stark shift in $\log _{10}(\mathrm{Rb} / \mathrm{K})$ between the forest floor and the exchangeable cations of the topmost mineral soil (Fig. 8 a), justified a boundary between the forest floor and the mineral soil. Atmospheric deposition of $\mathrm{K}$ and $\mathrm{Rb}\left(\phi_{\mathrm{K} \text {, dep }}\right.$ and $\phi_{\mathrm{Rb} \text {, dep }}$; $\mathrm{kg} \mathrm{ha}^{-1}$ year $\left.^{-1}\right)$ and uptake fluxes from the mineral soil ( $\phi_{\mathrm{K}}$, uptake and $\phi_{\mathrm{Rb}}$, uptake $)$ provided inputs of cations to the biopool, whereas leaching into the mineral soil ( $\phi_{\mathrm{K}}$, leach and $\phi_{\mathrm{Rb}}$, leach $)$ was the output.

The value of $\alpha_{\text {leach }}$ depends on the selectivity coefficient $k_{\mathrm{Rb} / \mathrm{K}}$ in Eq. (9). In previous work on various kinds of soil, Baligar and Barber (1978a) reported $k_{\mathrm{Rb} / \mathrm{K}}$ in the range of $1.9-4.4$; i.e., $\mathrm{Rb}^{+}$is sorbed preferentially over $\mathrm{K}^{+}$by the exchange complex. An overall range in $\alpha_{\text {leach }}$ of $0.1-0.3$ was obtained 


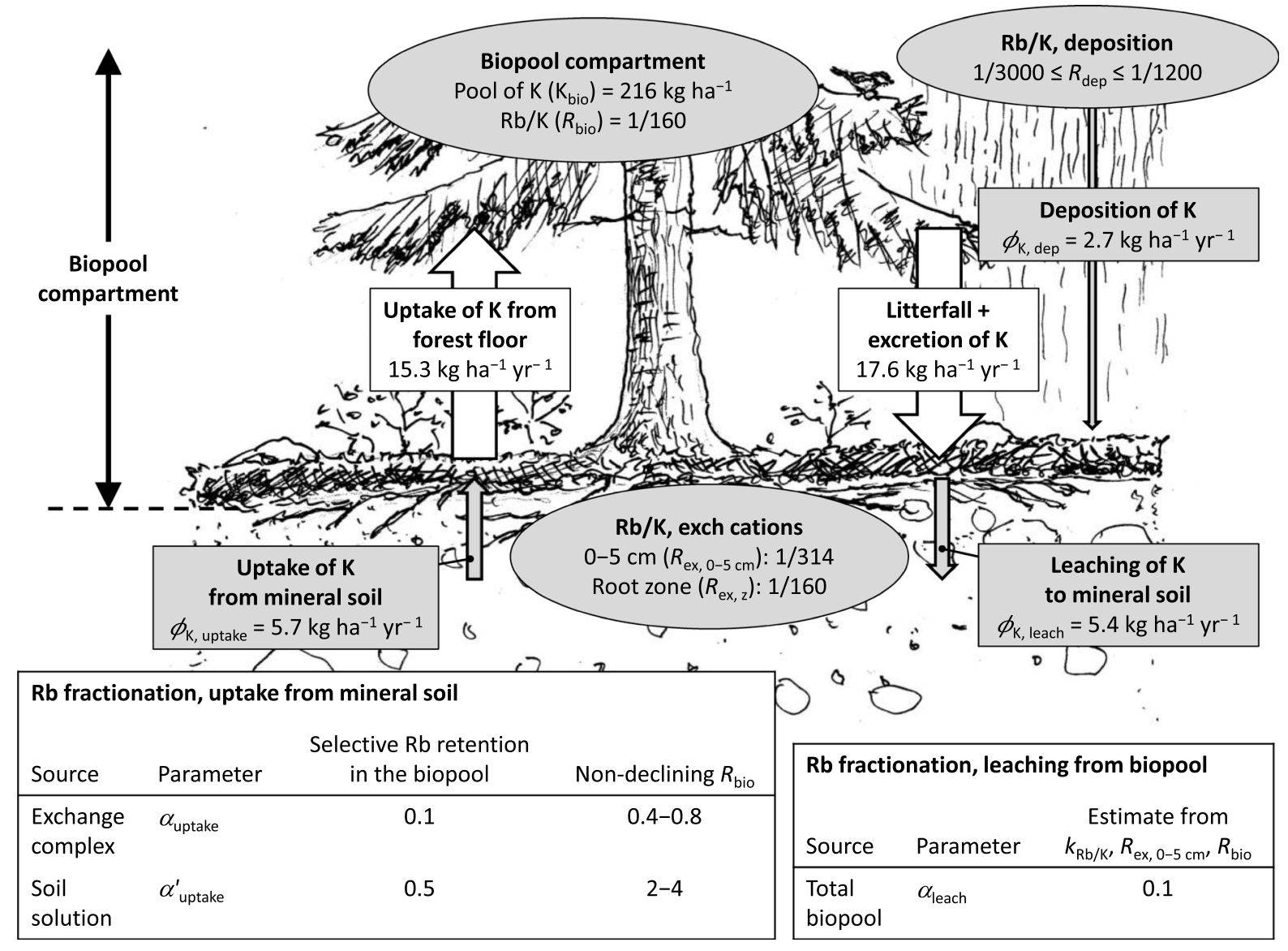

Fig. 10 Pools, fluxes, $\mathrm{Rb} / \mathrm{K}$ weight ratios (' $R$ ') used for the fractionation model describing the cycling of $\mathrm{K}$ and $\mathrm{Rb}$; discrimination coefficients (' $\alpha$ ') estimated for uptake from and leaching into the mineral soil (variables are explained in Table 3). The large exchange between the biomass and forest

using high and low values of $k_{\mathrm{Rb} / \mathrm{K}}$, the current $R_{\mathrm{ex}}, 0-5 \mathrm{~cm}(1 / 314)$ and the range of $R_{\mathrm{bio}}$ in the control plots (1/170-1/150; Table 6). As reported by Baligar and Barber (1978a), $k_{\mathrm{Rb} / \mathrm{K}}$ does not depend on the clay or humus content, but varies inversely with the content of exchangeable $\mathrm{K}$ in the soil. The low content in the Skogaby soil (Fig. 5a; cf. 2-4 mmol $_{\mathrm{c}} \mathrm{kg}^{-1}$ in Baligar and Barber 1978a) suggests a $k_{\mathrm{Rb} / \mathrm{K}}$ close to the maximum value of 4.4. This yields $\alpha_{\text {leach }}=0.1$.

As to $\alpha_{\text {uptake, a lower possible value that would }}$ yield preferential retention of $\mathrm{Rb}$ in the biopool was obtained from Eq. (12). The generally shallow cycling of K suggests that the majority of $\phi_{\mathrm{K}}$, uptake originated from the upper part of the mineral soil. According to data of Persson et al. (1995), the relative root distribution rapidly declined with increasing depth floor (white boxes and arrows) were not included in the model but are shown for comparison (arrow width proportional to flux). Fluxes of $\mathrm{K}$ were derived from data of Simonsson et al. (2015)

similarly to exchangeable K (Fig. 5a); using their data, a value of $R_{\mathrm{ex}, z}=1 / 160$ was obtained as the ratio of root-density weighted quantities of $\mathrm{Rb}$ and $\mathrm{K}$ $\left(\mathrm{kg} \mathrm{ha}^{-1}\right.$ ). Due to the similarity of $R_{\mathrm{bio}}$ and $R_{\mathrm{ex}, z}$, it follows from Eq. (12) that preferential retention of $R b$ would occur if $\alpha_{\text {uptake }}$ was equal to $\alpha_{\text {leach }}$ or higher; i.e., $>0.1$. A corresponding $\alpha_{\text {uptake }}^{\prime}>0.5$ was obtained from Eq. (13).

A high estimate of $\alpha_{\text {uptake }}$ was obtained from Eq. (18), based on the arbitrary assumption of stationary (non-declining) $R_{\text {bio }}$ and the $R_{\mathrm{ex}, z}$ estimated above. Working with nominal (central) values, an average $\mathrm{K}_{\mathrm{bio}}$ of $216 \mathrm{~kg} \mathrm{ha}^{-1}$ is obtained from Table 6 . With a $k_{\mathrm{Rb} / \mathrm{K}}$ value of 4.4 and $R_{\mathrm{dep}}$ values within the typical global range for rain water, 1/3300-1/1200 (Chaudhuri et al. 2007), a ten-year projection of the 
average $R_{\text {bio }}$ of control plots would remain inside the present range for the control plots, if $\alpha_{\text {uptake }}$ was in the range of $0.4-0.8$. The corresponding range of $\alpha^{\prime}$ uptake was 2-4.

\section{Discussion}

Sources of weathering loss of K at Skogaby

The overall loss of $\mathrm{K}$ (22 $\mathrm{Mg} \mathrm{ha}^{-1}$; Table 5) and a soil age of 15,000 years puts Skogaby roughly in the middle of the range of annual $\mathrm{K}$ weathering rates (1-7 $\mathrm{mmol}_{\mathrm{c}} \mathrm{m}^{-2}$ year $^{-1}$ ) estimated by Stendahl et al. (2013) for 16 podzolised Swedish glacial tills of granitic origin. By virtue of their quantitative dominance of the K geochemistry, feldspars accounted for half or more of this loss (Table 5).

Although 2:1 minerals contained only $10 \%$ of the $\mathrm{K}$ in the soil prior to weathering, they contributed of the order of $20-50 \%$ of the overall weathering losses of $\mathrm{K}$ within $0-70 \mathrm{~cm}$ depth in the profile (Table 5), indicating a higher reactivity of these phases. The estimation of the present stock of $\mathrm{K}$ in 2:1 minerals based on $\mathrm{K}_{\mathrm{HCl}}$ can be criticised, because the relationship between extracted $\mathrm{K}$ and the total content of $\mathrm{K}$ in 2:1 minerals (Eq. (5)) is likely to vary with the degree of weathering in different horizons (Ross and Kodama 1970; Ross 1971) and with the proportion of the mixed-layer phases that are particularly susceptible to dissolution by the $\mathrm{HCl}$ extraction (Andrist-Rangel et al. 2013). However, by allowing the coefficient $a$ of Eq. (5) to vary between wide limits, we intended to establish an interval of the present $\mathrm{K}$ in 2:1 minerals with a reasonable level of confidence. It is obvious that the selection of scenario to estimate the pre-weathering quantities had a greater influence on the result (Table 5).

Evidence has been reported for neoformation of smectite in the E horizon (Egli et al. 2002) and kaolinite in the B horizon (Cornelis et al. 2014) of acidic forest soils. To our knowledge, evidence has not been presented for neoformation of vermiculitic phases in Podzol B horizons. Soil vermiculite is usually assumed to form through transformations of a mica or chlorite precursor (Douglas 1989). Any Fe(II) occurring in a trioctahedral precursor may become oxidised, leading to expulsion of some of the oxidised $\mathrm{Fe}(\mathrm{III})$ from the lattice and a more dioctahedral structure of the transformed mineral (Wilson 1999). The dioctahedral nature of expandable phases at $0-5$ and $30-40 \mathrm{~cm}$ does not preclude a common origin with the 2:1 minerals in the $80-90 \mathrm{~cm}$ layer (Fig. 2a, b). The greater loss of $\mathrm{K}$ implied by the 'transformation scenario' (Table 5) appears in line with most previous research on clay minerals in podzolised soils.

The $\mathrm{K} / \mathrm{Rb}$ ratios indicate extensive loss of $\mathrm{K}$ from 2:1 minerals in the upper 50 or $60 \mathrm{~cm}$ of the profile, followed by re-fixation of $\mathrm{K}$ and $\mathrm{Rb}$ at a lower ratio than in the parent mineral. Whereas the ratio obtained from $\mathrm{HCl}$ extracts at the reference depth $70-100 \mathrm{~cm}$ is within the normal ranges for biotite and muscovite compiled by Shaw (1968), the maximum $\mathrm{Rb}$ content around $30 \mathrm{~cm}$ in all plots (Fig. $3 \mathrm{~b}$, Fig. 8) corresponds to a $\mathrm{K} / \mathrm{Rb}$ ratio of only 55 . Muscovite is normally considerably poorer in $\mathrm{Rb}$ than biotite, with $\mathrm{K} / \mathrm{Rb}$ ratios typically in the range 200-300 (Shaw 1968); the corresponding $\log _{10}(\mathrm{Rb} / \mathrm{K})$ in Fig. 8 would be -2.5 to -2.3 . Together with the dioctahedral nature of 2:1 phases present in the horizon, the low $\mathrm{K} / \mathrm{Rb}$ ratio appears highly atypical for a simple residue of dioctahedral mica. During sorption and fixation in the soil, on the other hand, monovalent cations larger than $\mathrm{K}^{+}$are generally preferred over the latter (Sawhney 1964; Heier and Billings 1970; Wyttenbach et al. 1995b; Kabata-Pendias 2001), and K/Rb ratios can be expected to decline during alteration of the parent material.

The role of clay minerals in the present $\mathrm{K}$ cycle at Skogaby

The question arises, what role clay minerals play in the cycling of $\mathrm{K}$ on a shorter term. Cation exchange sites in the forest floor and top mineral soil may store part of the $\mathrm{K}$ that is recycled after clear-felling and during the following establishment of a new stand. Knoepp and Swank (1997) observed a three-fold increase in exchangeable $\mathrm{K}$ of the $0-10$ - and 10-20-cm layers of the soil following conventional timber harvesting. However, with a cation exchange capacity of 240 $\mathrm{mmol}_{\mathrm{c}} \mathrm{kg}^{-1}$ (Table 1) and $50-65 \mathrm{Mg} \mathrm{ha}^{-1}$ of dry matter in the humus layer, the present biomass $\mathrm{K}$ would occupy an unrealistically high share, $30-50 \%$, of the binding capacity if transferred to the forest floor (cf. 4.4\% K saturation in 1987; Table 1). It is very unlikely that $\mathrm{K}$ fluxes associated with clear-felling and stand development could proceed without involving 
the mineral soil. Also, the data in Fig. 10 indicate that $25 \%$ of the $\mathrm{K}$ cycling in the present stand goes via the mineral soil. The reasonable match between the depletion of $\mathrm{K}_{\mathrm{HCl}}$ in the profile on one hand ( $\Delta \mathrm{K}_{\mathrm{HCl}}$ ', Table 6) and the $\mathrm{K}$ accumulated in the biomass on the other hand (' $\mathrm{K}_{\text {biomass }}$ ') suggests that the $\mathrm{K}_{\mathrm{HCl}}$ pool is deeply affected by the bioaccumulation of $\mathrm{K}$ during a single generation of trees. The depletion of $\mathrm{K}_{\mathrm{HCl}}$ represents only of the order of $3 \%$ of the overall $\mathrm{K}$ loss from 2:1 minerals according to the transformation scenario (Table 5). Previous results, however, indicate that $\mathrm{K}_{\mathrm{HCl}}$ represents a pool that is sufficiently well defined in terms of reactivity, to make a comparison with the $\mathrm{K}$ pool in the present biomass meaningful. In 40-year-long field experiments on agricultural soils, changes in the non-exchangeable portion of $\mathrm{K}_{\mathrm{HCl}}$ on the average accounted for $40 \%$ of the balance of uptake and fertiliser applications (Simonsson et al. 2007). Temporal trends of $\mathrm{K}_{\mathrm{HCl}}$ deserve attention in forthcoming studies on $\mathrm{K}$ dynamics also in forest ecosystems.

The biopool favours cycling of $\mathrm{K}$ by two different mechanisms at the same time

Although $\mathrm{K} / \mathrm{Rb}$ ratios (expressed as $\log _{10}(\mathrm{Rb} / \mathrm{K})$ in Fig. 8) were similar in biomass, forest floor and clay minerals, the fractionation occurring when the ions were transferred from the soil to the biopool and back to the soil again makes it difficult to use the element ratios to identify any particular mineralogical origin of the $\mathrm{K}$ cycling in the system. However, an interpretation of the discrimination coefficients gives further insight into the conditions controlling the cycle of $\mathrm{K}$. An overall understanding of the $\mathrm{Rb}$ gradients involves three phenomena: Preferential retention of $\mathrm{Rb}$, preferential uptake of $\mathrm{K}$ and transport of $\mathrm{Rb}$.

As to the preferential retention of $\mathrm{Rb}$, the low value of $\alpha_{\text {leach }}$ in our fractionation model is qualitatively in agreement with the observation of Peltola et al. (2008), who consistently found a preferential export of $\mathrm{K}$ over $\mathrm{Rb}$ from decomposing litter incubated in boreal forests. Preference of exchange sites for $\mathrm{Rb}^{+}$over $\mathrm{K}^{+}$is also expressed by the value of the selectivity coefficient, $k_{\mathrm{Rb} / \mathrm{K}}>1$, as reported by Baligar and Barber (1978a). With the forest floor acting as a 'filter', tending to retain $\mathrm{Rb}$ and let $\mathrm{K}$ through, the exchange complex at $0-20 \mathrm{~cm}$ depth in the mineral soil became depleted in $\mathrm{Rb}$ (Fig. 8). Exchangeable $\mathrm{K}$ and $\mathrm{Rb}$ are the most labile pools in the soil measured in the study, whereas the $\mathrm{HCl}$-extractable pools represent interlayers in 2:1 minerals that are reactive on a somewhat longer term. The relatively Rb-rich interlayers apparently were in disequilibrium with the $\mathrm{Rb}$ depleted exchange complex in the top $30 \mathrm{~cm}$ of the mineral soil of the control plots (Fig. 8) and may lose $\mathrm{Rb}$ over time, leading to a decline in $\log _{10}(\mathrm{Rb} / \mathrm{K})$ in this part of the profile. Further evidence is obtained from the ratios of $\mathrm{K}_{\mathrm{ex}} / \mathrm{K}_{\mathrm{HCl}}$ and $\mathrm{Rb}_{\mathrm{ex}} / \mathrm{Rb} \mathrm{HCl}_{\mathrm{HCl}}$ (Fig. 5d, e), which suggest that a more intense cycling of $\mathrm{K}$ than $\mathrm{Rb}$ in the upper part of the profile to some extent withheld the former element from fixation by clay minerals. On the average, the mineral soil contained $21 \mathrm{~kg} \mathrm{ha}^{-1}$ of $\mathrm{K}$ in the upper $20 \mathrm{~cm}$. A cycling of approximately $5 \mathrm{~kg} \mathrm{ha}^{-1}$ year $^{-1}$ (Fig. 9) implies a mean residence time of 4 years with respect to this pool. The corresponding exchangeable $\mathrm{Rb}$ was $0.11 \mathrm{~kg} \mathrm{ha}^{-1}$. With a $\phi_{\mathrm{K}}$, leach of $5 \mathrm{~kg} \mathrm{ha}^{-1}$ year $^{-1}$, $\alpha_{\text {leach }}$ of 0.1 and $R_{\text {bio }}$ as in the control plots (1/160), Eq. (6) yields an annual leaching of $\mathrm{Rb}$ into the mineral soil of $0.003 \mathrm{~kg} \mathrm{ha}^{-1}$ year $^{-1}$. The implied mean residence time with respect to exchangeable $\mathrm{Rb}$ within $0-20 \mathrm{~cm}$ depth is 35 years.

Preferential $\mathrm{Rb}$ retention in the biopool indicates a value of $\alpha_{\text {uptake }}>0.1\left(\alpha^{\prime}\right.$ uptake $\left.>0.5\right)$. However, evidence for preferential uptake of $\mathrm{K}$ is observed below $50 \mathrm{~cm}$, where the high $\log _{10}(\mathrm{Rb} / \mathrm{K})($ Fig. 8) indicates downward migration of $\mathrm{Rb}$ from a source in the overlying horizons. Such a source is most readily understood if $\mathrm{Rb}$ is being 'left over' during preferential uptake of $\mathrm{K}$. This results in an apparent disequilibrium between the exchange complex and the interlayer of 2:1 minerals. Over time, the relative $\mathrm{Rb}$ content of these minerals can be expected to increase. The very low ratio of $\mathrm{K}_{\mathrm{ex}} / \mathrm{K}_{\mathrm{HCl}}$ below $50 \mathrm{~cm}$ (Fig. $5 \mathrm{~d}$ ) suggests that $\mathrm{K}$ is only sparsely recycled into the deep mineral soil. The somewhat higher ratio for $\mathrm{Rb}$, and the high $\log _{10}(\mathrm{Rb} / \mathrm{K})$ of exchangeable cations in this part of the profile (Fig. 8), is consistent with downward migration of $\mathrm{Rb}$. A fractionation coefficient of $\alpha_{\text {uptake }}<1$ would imply an uptake of more $\mathrm{K}$ than expected from the ratio of the exchangeable cations, and would lead to a decline in $\mathrm{K} / \mathrm{Rb}$ ratios at exchange- and fixation sites in the deeper horizons, which do not experience the impact of preferentially cycled K.

The overall range of $\alpha_{\text {uptake, permitting both }}$ preferential retention of $\mathrm{Rb}$ and preferential uptake 
of $\mathrm{K}$, is $0.1-1$, which comprises the range in $\alpha_{\text {uptake }}$ of 0.4-0.8 required for a stable (non-declining) $R_{\text {bio }}$ (Fig. 10). Hence, the fractionation model demonstrates that the present pools and fluxes observed in the control plots are consistent both with a preferential retention of $\mathrm{Rb}$ in the biopool, and with discrimination against $\mathrm{Rb}$ from the exchange complex in the root zone. Using $k_{\mathrm{Rb} / \mathrm{K}}$ of 4.4 , the corresponding range of $\alpha$ uptake can be estimated at $0.5-4$. Because this range comprises values $>1$, it cannot be ascertained whether the preference for $\mathrm{K}$ during uptake by root reflects a preference for $\mathrm{K}$ in the soil solution, or is the result of a stronger sorption of $\mathrm{Rb}$ onto soil particles. Data in the literature indicate that very strong preference for $\mathrm{K}$ or $\mathrm{Rb}$ is unlikely. The pioneer work by Collander (1941), who investigated 20 plant species, indicated no preference for either of the two elements during two months of hydroponic cultivation, leading to the classic conclusion that plant roots were unable to distinguish between $\mathrm{K}^{+}$and $\mathrm{Rb}^{+}$. Several in vitro experiments with excised maize roots have indicated slightly dissimilar uptake rates during the very short time intervals used in the experiments (typically 1-2 h), occasionally with preference for $\mathrm{Rb}$ (Maas and Legett 1968). The study of Baligar and Barber (1978b), with entire corn and onion plants in solution culture, indicated a fractionation factor of approximately 0.5 with respect to solution concentrations. Based on concentrations in soil solution and biomass, White et al. (2012) estimated a $\mathrm{Rb} / \mathrm{K}$ fractionation factor of 0.83 for uptake by grassland vegetation.

The accumulation measured as $\Delta \mathrm{Rb}_{\mathrm{HCl}}$ corresponded to 2-6 times the $\mathrm{Rb}$ in the present biomass, and an overall transport mechanism needs to be considered. A rough calculation indicates that cycling through the biomass, with fractionation as outlined above, was sufficient to get the $\mathrm{Rb}$ in place. Consider, for instance, a $\Delta \mathrm{Rb}_{\mathrm{HCl}}$ of $5 \mathrm{~kg} \mathrm{ha}^{-1}$ (Table 6) and an exchange complex with a $\mathrm{K} / \mathrm{Rb}$ ratio in equilibrium with clay minerals as extracted by $\mathrm{HCl}$ in the reference horizons at 70-100 cm depth $(\mathrm{K} / \mathrm{Rb}=150)$. With the smallest estimate of $\alpha_{\text {uptake }}, 0.1$, the cumulative uptake according to Eq. (10) would have to involve $7500 \mathrm{~kg} \mathrm{ha}^{-1}$ of $\mathrm{K}$. An annual cycling of approximately $5 \mathrm{~kg} \mathrm{ha}^{-1}$ of $\mathrm{K}$ suggests that this may be accomplished within 1500 years. If, instead, exchangeable $\mathrm{K}$ and $\mathrm{Rb}$ were offered at a ratio as in the bulk mineral soil (370; Table 6), it would take 3700 year. The required time could be considerably less, if the discrimination against $\mathrm{Rb}$ was weaker, or more, if the annual flux of $\mathrm{K}$ was smaller than at present.

Preferential retention of $\mathrm{Rb}$ occurs both in the biopool and in clay minerals. The latter mechanism was responsible for the elevated $\mathrm{Rb}$ concentrations in the upper half metre of the mineral soil; the preferential cycling of $\mathrm{K}$ was responsible for pushing the $\mathrm{Rb}$ peak down to its current position around $40 \mathrm{~cm}$, and further downward migration may be expected. The biopool at Skogaby had a relatively low $\mathrm{K} / \mathrm{Rb}$ ratio compared to similar ecosystems in Sweden (Peltola et al. 2008), Finland and northwest Russia (Reimann et al. 2001), where $\mathrm{K} / \mathrm{Rb}$ ratios generally were in the range 200 to $>500$ rather than 100-200 as in our study. The significance of the generally low $\mathrm{K} / \mathrm{Rb}$ ratio in the igneous rocks of the Fennoscandian shield was pointed out by Peltola et al. (2008). However, in the compilation of data made by Reimann et al. (2001), spruce biomass and $\mathrm{O}$ horizons on the average had considerably higher $\mathrm{K} / \mathrm{Rb}$ ratios than $\mathrm{C}$ horizon soils, in contrast to the situation at Skogaby. Wyttenbach et al. (1995a) argued that the highly variable K/Rb ratios of plants, even within a given plant species, indicates that the uptake of $\mathrm{Rb}^{+}$is to a greater extent controlled by the precise sorption properties of the soil than by fractionation at the solution-plant interface. Uptake experiments from considerably more clayey substrates than the soil at Skogaby illustrate this. Chaudhuri et al. (2007) reported $\mathrm{K} / \mathrm{Rb}$ ratios ranging from 1500 to 2600 for plants grown in smectite and illite clay soil, and Semhi et al. (2012) obtained $\mathrm{K} / \mathrm{Rb}$ ratios of 900-4000 in spinach grown in a substrate containing $85 \%$ illite with an initial $\mathrm{K} / \mathrm{Rb}$ ratio of 278 . It may be speculated that the relation between $\mathrm{K} / \mathrm{Rb}$ in biomass and soil contains information on the extent to which fixation in and release from clay minerals interfere in the cycling of $\mathrm{K}$ in the ecosystem.

$\mathrm{K} / \mathrm{Rb}$ ratios as affected by treatments

During early years of the field experiment, the NS treatment yielded faster tree growth and a larger bioaccumulation of $\mathrm{K}$ and other base cations compared to the control (Nilsson et al. 2001). However, from 1991 tree growth in the NS treatment started to decline relative to the control, and became less than in the control plots from 1997 and onwards. The annual average total proton load of NS plots was 
approximately ten times the $700 \mathrm{kmol}_{\mathrm{c}} \mathrm{ha}^{-1}$ year $^{-1}$ of the control plots, as estimated by Bergholm and Berggren (2003) for the period 1988-1998. As stated by the authors, the enhanced proton load was almost entirely associated with uptake and nitrification of the added ammonium ions, with uptake being the greater of the two. With $\mathrm{NH}_{4}{ }^{+}$ions partly penetrating into the mineral soil, as evidenced by elevated concentrations of $\mathrm{NH}_{4}{ }^{+}$measured in soil solutions from $50 \mathrm{~cm}$ depth of NS plots (Bergholm et al. 2003), mineralisation in the forest floor of $\mathrm{N}$ taken up at some depth in the mineral soil resulted in alkalisation of the former and acidification of the latter, as seen in Fig. 6.

Our data indicate that cation exchange with $\mathrm{NH}_{4}{ }^{+}$ added to NS plots displaced some of the Rb into the topmost mineral soil (cf. Figures 3b, 5c, 8). It is highly probable that the massive applications of $\mathrm{NH}_{4}{ }^{+}$also displaced $\mathrm{K}^{+}$ions to the mineral soil. However, the concentrations in the forest floor (Fig. 3a) and mineral soil (Fig. 5a) were hardly affected by the NS treatment. Bergholm and Berggren (2003) noticed that the leaching of $\mathrm{K}^{+}$at $50 \mathrm{~cm}$ depth, unlike other base cations, was mostly unaffected by the NS treatment and that a low $\mathrm{K} / \mathrm{N}$ ratio in the needles indicated a high demand for $\mathrm{K}$ in the spruce stand, apparently preventing loss of displaced $\mathrm{K}$ from the profile. The pulse of $\mathrm{Rb}$, but not of $\mathrm{K}$, moving into the mineral soil of the NS plots lends further support to the conclusion that K was taken up preferentially over Rb by the vegetation.

The $\mathrm{K} / \mathrm{Rb}$ ratio of the biopool and of exchangeable cations is likely to be a sensitive indicator of changes in the cation cycles. Previous work suggested that deteriorated $\mathrm{K}$ availability due to acid leaching of the soil may enhance the vegetation's uptake of $\mathrm{Rb}$ (Drobner and Tyler 1998), which readily propagates to higher tropic levels in the ecosystem (Nyholm and Tyler 2000). Given the small value of $\alpha_{\text {leach }}$, Eq. (18) suggests that a declining uptake of $\mathrm{K}$ or extensive leaching of $\mathrm{K}$ from the biopool would tend to enhance its content of $\mathrm{Rb}$ relative to $\mathrm{K}$. The somewhat higher $\log _{10}(\mathrm{Rb} / \mathrm{K})$ in the biopool of NS plots (cf. Table 6) corroborates this prediction, although the model parameters were not based on pools and fluxes in the

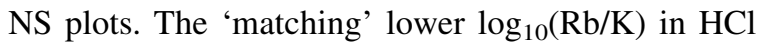
extracts of soils from the NS plots is intriguing. However, the potentially long time involved in evolving the $\Delta \mathrm{Rb}_{\mathrm{HCl}}$ suggests that this apparent treatment effect might be a result of spatial heterogeneity present in the soil before the experiment started.

\section{Conclusions}

1. From 0-70 cm depth an overall Holocene loss of $22 \mathrm{Mg} \mathrm{ha}^{-1}$ of $\mathrm{K}$ was calculated based on geochemical gradients of $\mathrm{K}$, Ti and $\mathrm{Zr}$. In relation to Hypothesis 1, weathering of $\mathrm{K}$ feldspars contributed half or more of this loss. However, K-bearing 2:1 minerals appeared relatively more reactive, contributing $20-50 \%$ of the loss despite containing only $10 \%$ of the bulk mineral $\mathrm{K}$ of the soil before the start of weathering. Pool sizes suggest that $\mathrm{K}$ in interlayers of clay minerals was an active reservoir of $K$ to consider at the time scale of one or a few generations of trees, even in this soil with its low content of clay minerals and high content of feldspars.

2. $\mathrm{K} / \mathrm{Rb}$ ratios in $\mathrm{HCl}$ extracts from 0 to $70 \mathrm{~cm}$ depth of the soil indicated extensive loss and re-fixation of $\mathrm{K}$ and $\mathrm{Rb}$ at a lower ratio (higher relative $\mathrm{Rb}$ content) than in the parent material. In relation to Hypotheses 2, the $\mathrm{Rb}$ accumulated in the profile $\left(\Delta \mathrm{Rb}_{\mathrm{HCl}}\right.$ in Table 6$)$ may be the result of cycling of several $\mathrm{Mg} \mathrm{ha}^{-1}$ of $\mathrm{K}$ during centuries to millennia.

3. Both clay minerals around $40 \mathrm{~cm}$ depth and the pools of biomass and forest floor showed a K/Rb ratio that was significantly lower compared to the feldspar-dominated bulk pool in the soil. This indicates preferential retention of $\mathrm{Rb}$, both by clay minerals and the forest floor. In addition, the present Norway spruce stand apparently absorbed $\mathrm{K}$ and $\mathrm{Rb}$ at a higher ratio than presented by the exchange complex in the mineral soil, either because $\mathrm{Rb}$ was more difficult to take up due to stronger adsorption onto soil particles, or because of true preference of the roots for $\mathrm{K}$ over $\mathrm{Rb}$ in the soil solution.

4. In relation to Hypothesis 3, it appears unlikely that effects of treatments during a single generation of trees would affect the $\mathrm{K} / \mathrm{Rb}$ ratio in the $\mathrm{HCl}$ extracts to a measurable extent. On the other hand, our $\mathrm{K} / \mathrm{Rb}$ fractionation model predicts that a declining uptake from the mineral soil, and/or extensive leaching losses of $\mathrm{K}$ from the forest 
floor, would increase the relative $\mathrm{Rb}$ content in the biopool (biomass + forest floor), and vice versa.

Acknowledgements Archive samples, archive data and help with digestion of biological samples were kindly provided by colleagues at the Department of Ecology, SLU: Dr. Per-Olov Brandtberg and Dr. Bengt Olsson. A critical discussion on pools and fluxes during the development of the $\mathrm{K} / \mathrm{Rb}$ fractionation model was provided by Dr. Mats Larsbo at the Department of Soil and Environment, SLU. The study was performed as part of the Environmental Monitoring and Assessment programme at SLU and the 'strong research environment' QWARTS (Quantifying Weathering rates for Sustainable Forestry), financed by the Swedish Research Council Formas (Grant No 2011-1691)

Open Access This article is distributed under the terms of the Creative Commons Attribution 4.0 International License (http:// creativecommons.org/licenses/by/4.0/), which permits unrestricted use, distribution, and reproduction in any medium, provided you give appropriate credit to the original author(s) and the source, provide a link to the Creative Commons license, and indicate if changes were made.

\section{References}

Ahrens LH (1965) Distribution of the elements in our planet. McGraw-Hill Book Company, New York

Akselsson C, Westling O, Sverdrup H, HOlmqvist J, Thelin G, Uggla E, Malm G (2007) Impact of harvest intensity on long-term base cation budgets in Swedish forest soils. Water Air Soil Pollut Focus 7:201-210

Andrist-Rangel Y, Simonsson M, Andersson S, Öborn I, Hillier S (2006) Mineralogical budgeting of potassium in soil: a basis for understanding standard measures of reserve potassium. J Plant Nutr Soil Sci 169:605-615

Andrist-Rangel Y, Simonsson M, Öborn I, Hillier S (2013) Acid-extractable potassium in agricultural soils: source minerals assessed by differential and quantitative X-ray diffraction. J Plant Nutr Soil Sci 176:407-419

Baligar VC, Barber SA (1978a) Potassium and rubidium adsorption and diffusion in soil. Soil Sci Soc Am J 42:251-254

Baligar VC, Barber SA (1978b) Potassium uptake by onion roots characterized by potassium/rubidium ratio. Soil Sci Soc Am J 42:618-622

Barré P, Velde B, Abbadie L (2007a) Dynamic role of "illitelike" clay minerals in temperate soils: facts and hypotheses. Biogeochem 82:77-88

Barré P, Velde B, Catel N, Abbadie L (2007b) Soil-plant potassium transfer: impact of plant activity on clay minerals as seen from X-ray diffraction. Plant Soil 292:137-146

Barré P, Velde B, Fontaine C, Catel N, Abbadie L (2008) Which 2:1 clay minerals are involved in the soil potassium reservoir? insights from potassium addition or removal experiments on three temperate grassland soil clay assemblages. Geoderma 146:216-223

Bergholm J, Jansson P-E, Johansson U, Majdi H, Nilsson LO, Persson H, Rosengren-Brink U, Wiklund K (1995) Air pollution, tree vitality and forest production. The Skogaby project. General description of a field experiment with Norway spruce in South Sweden. In: Nilsson LO, Hüttl RF, Johansson UT, Mathy P (eds) Nutrient Uptake and Cycling in Forest Ecosystems. Ecosystems Research Report 21. European Commission, pp 69-87

Bergholm J, Nilsson L-O, Johansson U (2001) Försöksområde och försöksuppläggning. In: Persson T, Nilsson L-O (eds) Skogabyförsöket: Effekter av långvarig kväve- och svaveltillförsel till ett skogsekosystem. Swedish Environmental Protection Agency, Report 5173, Stockholm, pp 17-23

Bergholm J, Berggren D, Alavi G (2003) Soil acidification induced by ammonium sulphate addition in a Norway spruce forest in southwest Sweden. Water Air Soil Pollut 148:87-109

Bouat M (1969) Application of potassium 40 and potassium 42 in agronomic research. Potash Rev Subj 28:1-14

Bowen HJM (1979) Environmental chemistry of the elements. Academic Press, London

Brimhall GH, Dietrich WE (1987) Constitutive mass balance relations between chemicalcomposition, volume, density, porosity, and strain in metasomatic hydrochemical systems-results on weathering and pedogenesis. Geochim Cosmochim Acta 51:567-587

Brimhall GH, Lewis CJ, Ford C, Bratt J, Taylor G, Warin O (1991) Quantitative geochemical approach to pedogenesis: importance of parent material reduction, volumetric expansion, and eolian influx in lateritization. Geoderma 51:51-91

Burr GO, Tanimoto T (1955) Absorption and distribution of nutrients in sugar cane. Part II: Potassium. Hawaiian Planters' Record 55:11-13

Calvaruso C, Mareschal L, Turpault MP, Leclerc E (2009) Rapid clay weathering in the rhizosphere of norway spruce and oak in an acid forest ecosystem. Soil Sci Soc Am J 73:331-338

Chaudhuri S, Clauer N, Semhi K (2007) Plant decay as a major control of river dissolved potassium: a first estimate. Chem Geol 243:178-190

Collander R (1941) Selective absorption of cations by higher plants. Plant Physiol 16:691-720

Cornelis J-T, Weis D, Lavkulich L, Vermeire M-L, Delvaux B, Barling J (2014) Silicon isotopes record dissolution and reprecipitation of pedogenic clay minerals in a podzolic soil chronosequence. Geoderma 235:19-29

Courchesne F, Gobran GR (1997) Mineralogical variations of bulk and rhizosphere soils from a Norway spruce stand. Soil Sci Soc Am J 61:1245-1249

Cox AE, Joern BC, Brouder SM, Gao D (1999) Plant-available potassium assessment with a modified sodium tetraphenylboron method. Soil Sci Soc Am J 63:902-911

Daniel E (2006) Beskrivning till jordartskartorna 4C Halmstad $\mathrm{NV}$, NO och SO (Description to the Quaternary maps 4C Halmstad NV, NO and SO). Sveriges geologiska undersökning, Uppsala 
Douglas LA (1989) Vermiculites. In: Dixon JB, Weed SB (eds) Minerals in soil environments. Soil Science Society of America, Madison, pp 635-674

Drobner U, Tyler G (1998) Conditions controlling relative uptake of potassium and rubidium by plants from soils. Plant Soil 201:285-293

Egli M, Zanelli R, Kahr G, Mirabella A, Fitze P (2002) Soil evolution and development of the clay mineral assemblages of a Podzol and a Cambisol in 'Meggerwald', Switzerland. Clay Miner 37:351-366

Egnér H, Riehm H, Domingo WR (1960) Untersuchungen über die chemische Bodenanalyse als Grundlage für die Beurteilung des Nährstoffzustandes der Böden. Ann Roy Agr Coll Sweden 26:199-215

Fanning DS, Keramidas VZ, El-Desoky MA (1989) Micas. In: Dixon JB, Weed SB (eds) Minerals in soil environments. Soil Science Society of America, Madison, Wisconsin, USA, pp 551-634

FAO (1990) FAO-UNESCO, Soil Map of the World. Revised Legend. Soils Bulletin 60. FAO, Rome

Hayashi H, Oinuma K (1964) Behaviours of clay minerals in treatment with hydrochloric acid, formamide and hydrogen peroxide. Clay Sci 2:75-91

Heier KS, Billings GK (1970) Rubidium. In: Wedepohl KH (ed) Handbook of Geochemistry. Springer, Berlin, II-4, Section 37

Hillier S (1999) Use of an air brush to spray dry samples for X-ray powder diffraction. Clay Miner 34:127-136

Hillier S (2003) Quantitative analysis of clay and other minerals in sandstones by X-ray powder diffraction (XRPD). Int Assoc Sedimentol Spec Publ 34:207-245

Kabata-Pendias A (2001) Trace elements in soils and plants. CRC Press, Boca Raton

Knoepp JD, Swank WT (1997) Long-term effects of commercial sawlog harvest on soil cation concentrations. For Ecol Manag 93:1-7

Kuhlmann H (1990) Importance of the subsoil for the K nutrition of crops. Plant Soil 127:129-136

Kuhlmann H, Claassen N, Wehrmann J (1985) A method for determining the K-uptake from subsoil by plants. Plant Soil 83:449-452

Läuchli A, Epstein E (1970) Transport of potassium and rubidium in plant roots. Plant Physiol 45:639-641

Lundqvist J, Wohlfarth B (2001) Timing and east-west correlation of south Swedish ice marginal lines during the Late Weichselian. Quat Sci Rev 20:1127-1148

Maas EV, Legett JE (1968) Uptake of ${ }^{86} \mathrm{Rb}$ and K by excised maize roots. Plant Physiol 43:2054-2056

Marschner H (1995) Mineral nutrition of higher plants. Academic Press, London

Menzel RG, Heald WR (1955) Distribution of potassium, rubidium, cesium, calcium and strontium within plants grown in nutrient solutions. Soil Sci 80:287-293

Moore DM, Reynolds RC (1997) X-ray diffraction and the identification and analysis of clay minerals. Oxford University Press, New York

Mortland MM, Ellis B (1959) Release of fixed potassium as a diffusion controlled process. Soil Sci Soc Am Proc 23:363-364

Mortland MM, Lawton K, Uehara G (1957) Fixation and release of potassium by some clay minerals. Soil Sci Soc Am Proc 21:381-384
Nilsson LO, Wiklund K (1994) Nitrogen uptake in a norway spruce stand following ammonium-sulfate application, fertigation, irrigation, drought and nitrogen-free-fertilization. Plant Soil 164:221-229

Nilsson L-O, Wiklund K (1995) Indirect effects of $\mathrm{N}$ and $\mathrm{S}$ deposition on a Norway spruce ecosystem. An update of findings within the Skogaby project. Water Air Soil Pollut 85:1613-1622

Nilsson L-O, Östergren M, Wiklund K (2001) Hur påverkades träden ovan mark? In: Persson T, Nilsson L-O (eds) Skogabyförsöket: Effekter av långvarig kväve- och svaveltillförsel till ett skogsekosystem. Swedish Environmental Protection Agency, Report 5173, Stockholm, pp 51-66

Nyholm NEI, Tyler G (2000) Rubidium content of plants, fungi and animals closely reflects potassium and acidity conditions of forest soils. For Ecol Manag 134:89-96

Olsson M, Melkerud PA (1989) Chemical and mineralogical changes during genesis of a Podzol from till in Southern Sweden. Geoderma 45:267-287

Olsson MT, Melkerud P-A (2000) Weathering in three podzolized pedons on glacial deposits in northern Sweden and central Finland. Geoderma 94:149-161

Olsson M, Rosén K, Melkerud P-A (1993) Regional modelling of base cation losses from Swedish forest soils due to whole-tree harvesting. Appl Geochem 8:189-194

Omotoso O, Mccarty DK, Hillier S, Kleeberg R (2006) Some successful approaches to quantitative mineral analysis as revealed by the 3rd Reynolds Cup contest. Clays Clay Miner 54:748-760

Paul AD, Gibson JA (1959) Amphoteric molecules, ions and salts. J Chem Educ 36:380-381

Peltola P, Brun C, Åström M, Tomilina O (2008) High K/Rb ratios in stream waters-exploring plant litter decay, ground water and lithology as potential controlling mechanisms. Chem Geol 257:92-100

Persson H, von Fircks Y, Majdi H, Nilsson LO (1995) Root distribution in a Norway spruce (Picea abies (L.) Karst.) stand subjected to drought and ammonium-sulphate application. Plant Soil 168-169:161-165

Prianischnikow D (1906) Feldspat und Glimmer als Kaliquellen. Die Landw Versuchs-St 63:152-156

Reed MG, Scott AD (1962) Kinetics of potassium release from biotite and muscovite in sodium tetraphenylboron solutions. Soil Sci Soc Am Proc 26:437-440

Reimann C, Koller F, Frengstad B, Kashulina G, Niskavaara H, Englmaier P (2001) Comparison of the element composition in several plant species and their substrate from a 1500 $000-\mathrm{km}^{2}$ area in Northern Europe. Sci Total Environ 278:87-112

Ross GJ (1971) Relation of potassium exchange and fixation to degree of weathering and organic matter content in micaceous clays of Podzol soils. Clays Clay Miner 19:167-174

Ross GJ, Kodama H (1970) Differential release of potassium from interstratified mica clay minerals as related to probable differences in their mica layer components. Clays Clay Miner 18:151-156

Salminen R (2005) Rubidium (available at: Rb chapter at: http:// weppi.gtk.fi/publ/foregsatlas/). Geochemical Atlas of Europe. FOREGS, pp 299-304 
Sawhney BL (1964) Sorption and fixation of microquantities of Cs by clay minerals: effect of saturating cations. Soil Sci Soc Am Proc 28:183-186

Schulze DG (1986) Correction of mismatches in 2-theta scales during differential X-ray diffraction. Clays Clay Miner 34:681-685

Semhi K, Clauer N, Chaudhuri S (2012) Variable element transfers from an illite-rich substrate to growing plants during a three-month experiment. Appl Clay Sci 57:17-24

Shaw DM (1968) A review of K-Rb fractionation trends by covariance analysis. Geochim Cosmochim Acta 32:573-601

Simonsson M, Andersson S, Andrist-Rangel Y, Hiller S, Mattsson L, Öborn I (2007) Potassium release and fixation as a function of fertilizer application rate and soil parent material. Geoderma 140:188-198

Simonsson M, Hillier S, Öborn I (2009) Changes in clay minerals and potassium fixation capacity as a result of release and fixation of potassium in long-term field experiments. Geoderma 151:109-120

Simonsson M, Bergholm J, Olsson B, von Brömssen C, Öborn I (2015) Estimating weathering rates using base cation budgets in a Norway spruce stand on podzolised soil: analysis of fluxes and uncertainties. For Ecol Manag 340:135-152

Ståhlberg S (1958) Om markens kaliumtillgångar och metoder för deras värdering. J Royal Swed Acad Agric For 97:389-402

Stendahl J, Akselsson C, Melkerud P-A, Belyazid S (2013) Pedon-scale silicate weathering: comparison of the PROFILE model and the depletion method at 16 forest sites in Sweden. Geoderma 211-212:65-74

Taskaev E (1987) Neutron-activation determination of rubidium and cesium in mineral waters. $\mathrm{J}$ Radioanal Nucl Chem 118:319-322

Tripler CE, Kaushal SS, Likens GE, Walter MT (2006) Patterns in potassium dynamics in forest ecosystems. Ecol Lett 9:451-466
Turpault MP, Gobran GR, Bonnaud P (2007) Temporal variations of rhizosphere and bulk soil chemistry in a Douglas fir stand. Geoderma 137:490-496

Turpault MP, Righi D, Uterano C (2008) Clay minerals: precise markers of the spatial and temporal variability of the biogeochemical soil environment. Geoderma 147:108-115

Vakhmistrov DB, Zakharin AA (1968) Localization of the receptor in the self-regulation system of potassium accumulation by sunflower plants in connection with the hypothesis of cell carriers. Soviet Plant Physiol 15:495-500

Velde B, Peck T (2002) Clay mineral changes in the Morrow experimental plots, University of Illinois. Clays Clay Miner 50:364-370

Wallace A (1968) Retranslocation of $\mathrm{Rb}^{86}, \mathrm{Cs}^{137}$, and $\mathrm{K}$ to new leaf growth in bush beans. Plant Soil 29:184-188

Wedepohl H (1969) Handbook of geochemistry. Springer, Berlin:II-2 and II-4

White AF, Schulz MS, Vivit DV, Bullen TD, Fitzpatrick J (2012) The impact of biotic/abiotic interfaces in mineral nutrient cycling: a study of soils of the Santa Cruz chronosequence, California. Geochim Cosmochim Acta 77:62-85

Wilson MJ (1999) The origin and formation of clay minerals in soils: past, present and future perspectives. Clay Miner 34:7-25

Witter E, Johansson G (2001) Potassium uptake from the subsoil by green manure crops. Biol Agric Hortic 19:127-141

Wyttenbach A, Bajo S, Bucher J, Furrer V, Schleppi P, Tobler L (1995a) The concentrations of K, Rb and $\mathrm{Cs}$ in spruce needles (Picea abies Karst.) and in the associated soils. Z Pflanzenernähr Bodenk 158:499-504

Wyttenbach A, Furrer V, Tobler L (1995b) The concentration ratios plant to soil for the stable elements $\mathrm{Cs}, \mathrm{Rb}$ and $\mathrm{K}$. Sci Total Environ 173(174):361-367 